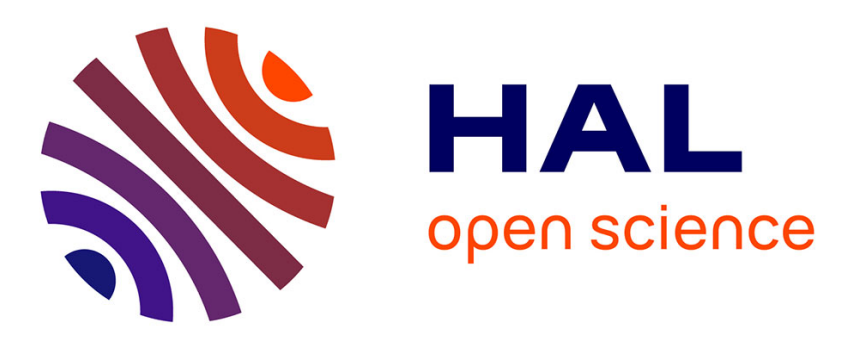

\title{
Seismic-refraction field experiments on Galapagos Islands: A quantitative tool for hydrogeology
}

\author{
M. Adelinet, C. Dominguez, J. Fortin, S. Violette
}

\section{To cite this version:}

M. Adelinet, C. Dominguez, J. Fortin, S. Violette. Seismic-refraction field experiments on Galapagos Islands: A quantitative tool for hydrogeology. Journal of Applied Geophysics, 2018, 148, pp.139 - 151. 10.1016/j.jappgeo.2017.10.009 . hal-01847671

\section{HAL Id: hal-01847671 \\ https://hal-ifp.archives-ouvertes.fr/hal-01847671}

Submitted on 23 Jul 2018

HAL is a multi-disciplinary open access archive for the deposit and dissemination of scientific research documents, whether they are published or not. The documents may come from teaching and research institutions in France or abroad, or from public or private research centers.
L'archive ouverte pluridisciplinaire HAL, est destinée au dépôt et à la diffusion de documents scientifiques de niveau recherche, publiés ou non, émanant des établissements d'enseignement et de recherche français ou étrangers, des laboratoires publics ou privés. 
(1)

(3)

(1)

${ }^{4}$ UPMC, UFR.918, 4 Place Jussieu, 75252 PARIS Cedex 05

${ }^{1}$ IFP Énergies nouvelles, 1 et 4 avenue Bois-Préau, 92852 RUEIL-MALMAISON Cedex

${ }^{2}$ UMR.8538 - Laboratoire de Géologie, ENS-PSL Research University, 24 rue Lhomond, PARIS

${ }^{3}$ Universidad Politecnica Salesiana, Departamento de Ingeniería Civil, Campus Sur, QUITO

\begin{abstract}
Due to their complex structure and the difficulty of collecting data, the hydrogeology of basaltic islands remains misunderstood, and the Galapagos islands are not an exception. Geophysics allows the possibility to describe the subsurface of these islands and to quantify the hydrodynamical properties of its ground layers, which can be useful to build robust hydrogeological models. In this paper, we present seismic refraction data acquired on Santa Cruz and San Cristobal, the two main inhabited islands of Galapagos. We investigated sites with several hydrogeological contexts, located at different altitudes and at different distances to the coast. At each site, a 2D P-wave velocity profile is built, highlighting unsaturated and saturated volcanic layers. At the coastal sites, seawater intrusion is identified and basal aquifer is characterized in terms of variations in compressional sound wave velocities, according to saturation state. At highlands sites, the limits between soils and lava flows are identified. On San Cristobal Island, the 2D velocity profile obtained on a mid-slope site (altitude $150 \mathrm{~m}$ ), indicates the presence of a near surface freshwater aquifer, which is in agreement with previous geophysical studies and the hydrogeological conceptual model developed for this island. The originality of our paper is the use of velocity data to compute field porosity based on poroelasticity theory and the Biot-Gassmann equations. Given that porosity is a key parameter in quantitative hydrogeological models, it is a step forward to a better understanding of shallow fluid flows within a complex structure, such as Galapagos volcanoes.
\end{abstract}

\title{
Keywords
}

seismic-refraction, volcanic rocks, water table, acoustic velocities, porosity

\section{Highlights}

- Seismic-refraction acquisition on volcanic islands

- Shallow hydrogeological targets: salted wedge or fresh-water aquifers

- Discussion about the applicability of the poroelastic theory for such acquisition

- Interpretation of velocities in terms of porosity using Biot-Gassmann theory 


\section{Introduction}

The hydrogeology of volcanic island is complex and remains poorly understood. Their hydrodynamic functioning relies on a disrupted geological setting up. Alternating active volcanic phases which contribute to the building up of the main edifice, combining basaltic lava flows or pyroclasts events with quiet periods, where weathering processes are dominant and alter the fresh outcropped basalts. As a result, the internal structure of volcanic islands looks like a layer-cake; where massive or fractured basaltic lavas are interlayered with weathered material (ashes, clayed soils, weathered basalts or pyroclasts...). Building an efficient flow model at island scale requires a large set of data: climatological and hydrological monitoring to constrain the water cycle on surface but also hydrodynamic parameters of the multi-layered system. in this context, porosity is one of the key parameters for such flow modelling as it controls to the groundwater storage.

On Galapagos Islands, a previous study provides porosity and permeability data of soils at different elevation points [Adelinet et al., 2008]. However, data is limited to the surface. The present study suggests a new approach, which allows the estimation of the field porosity of the substratum (at deeper levels) using its acoustic properties.

In order to investigate acoustic and petrophysical properties of Galapagos subsurface, we chose to use seismic-refraction methods. The advantage of seismic methods compared to electrical ones for instance is the direct relationship between acoustic velocities and porosity whereas electrical methods are generally only useful to determine position of water table in such complex geological structures [Revil et al., 2004; 2008].Indeed, accurate knowledge of seismic velocities helps to estimate the porosity of the groundwater formations. For instance in Garambois et al. [2002] porosity is inferred by using both $\mathrm{P}$ and $\mathrm{S}$ waves compared with GPR results. We are aware that only combined geophysical approaches can provide well-constraint hydrogeological models. However, as many studies have been performed on Galapagos islands during the last decade, we chose to focus our study only on the acoustic and petrophysical behaviour of both studied islands, Santa Cruz and San Cristobal.

Seismic refraction methods are generally used in oil industry for static corrections in processing of seismic reflection., and commonly in engineering applications (e.g. see Khalil and Hanafy [2008]). In hydrogeology, it is less employed due to the lack of resolution in depth and also due to the cost of an intensive processing. Moreover, seismic-refraction has some limitations, such as, when low-seismicvelocity layers are overlain by high-seismic-velocity layers [Haeni, 1981]. Nevertheless, seismicrefraction surveys have been used to describe the velocity structure of some basaltic islands, such as Canary Island [Bosshard \& MacFarlane, 1970; Banda et al., 1981] or Faeroe Islands [Pálmason, 1965]. A very interesting study has been performed in Iceland combining seismic tomography field experiments with laboratory ultrasonic measurements to obtain a comprehensive picture of the velocity systematics according lithology [Grab et al., 2015]. Generally, refraction survey carried out on $2 \mathrm{D}$ lines allows the mapping of velocities on a depth profile. Different limits could be seen as refractors for volumetric waves: interface between weathered and unweathered rocks, fracture 
areas and limits between dry and saturated layers [Mari, 1999]. Indeed, water table is a very effective refractor with P-wave velocities in saturated rocks generally more than $1500 \mathrm{~m} / \mathrm{s}$ [Kearey et al., 2013]. In our case, seismic refraction is used to assess subsurface acoustic properties. In such case, targets are close to the surface, less than $50 \mathrm{~m}$ deep, and therefore issues on depth resolution and cost are overcome. Interpretation of layer velocity can be assured as we expect an increasing gradient of velocity with depth at this scale. Indeed, if we consider the largest scale of the entire island, this assumption could not be validate due to the structural alternating sequence of lava flow deposits and soil/weathered rock, which could potentially results in a low velocity layer underlying a high velocity layer.

In this paper, rather than just present the velocity structure of the subsurface, we propose to go a step further by using velocity data to derive porosity. The present study is included into the Galapagos Islands Integrated Water Studies project (GIIWS), which begins in 2003 [d'Ozouville, 2007; d'Ozouville et al., 2008a, 2008b; Auken et al., 2009; Pryet, 2011a, 2011b; Pryet et al., 2012a, 2012b; Violette et al., 2014; Dominguez et al., 2016]. Note that before this project, no baseline data existed for hydrogeological understanding on Galapagos. The keypoint of the GIIWS is to use several datasets in order to build robust conceptual hydrogeological models for Santa Cruz and San Cristobal islands. Dataset are collected using in-situ measurements and indirect data, such as geophysical measurements. The integration of a large datasets is very important to understand the hydrogeological working of such complex structure as described on a Micronesian example by Ayers \& Vacher [1986], on La Reunion [Violette et al., 1997], on Mayotte island [Vittecoq et al., 2014] andon Martinique Island [Vittecoq et al., 2015].

The present paper is structured as follow: First, the acquisition on sites and the layouts on both islands are extensively presented. Second, we figure out the different 2D velocity profiles deduced from raw seismic data. Third, we interpret our velocity data in terms of porosity data in the poroelasticity framework. Finally we discuss the results in a global hydrogeological framework. 


\subsection{Sites description}

112

113

114

115

116

117

118

119

120

121

122

123

124

125

126

127

128

129

130

131

132

133

134

135

136

137

138

139

140

141

142

143

144

145

146

147

148

149

150

151

The archipelago is located on the Ecuador at about $1000 \mathrm{~km}$ west from the South America continent. Santa Cruz and San Cristobal Islands are respectively in the central and eastern part of the archipelago. Geologically they belong to the central sub province [Mc Birney and Williams, 1969; Bow, 1979; Geist et al., 1998]. Both islands are built from similar basaltic rocks and are exposed to similar climate conditions. However there are some differences between islands. In terms of age, San Cristobal is older than Santa Cruz with the more recently erupted lavas dated of 2.4 M.y. [Geist et al., 1986] against 1.3/0.95-0.05 M.y. on Santa Cruz [White et al., 1993]. The weathered cover is also different: $1 \mathrm{~m}$ on Santa Cruz compared to $10 \mathrm{~m}$ on San Cristobal [Geist et al., 1986]. On both islands, physical properties of soils evolved according to the elevation and the rainfall regime [Adelinet et al., 2008; Violette et al., 2014]. Soils are thicker, less porous and less permeable in altitude than near the coast.

In the frame of this study, two seismic campaigns have been carried out on Galapagos Islands. Three sites on Santa Cruz (SZ) Island were investigated in 2011 whereas six sites on San Cristobal (SC) Island were done in 2013. Experiments were carried out at the same time of the year, in the beginning of the cool season (July). Figure 1 presents maps of the sites location on both islands. Sites have been chosen according to their altitude and distance to sea. We defined three types of location: coastal, mid-slope and highlands (Table 1). Mid-slope and highland sites are always located on the windward side of the islands. Ground floors of sites present also different aspects (Figure 2): unweathered or weathered basalts, scoria cone, pyroclasts, soils, etc... Coastal sites have been chosen to estimate wave velocities of basaltic rocks where water table position is known, e.g. limit between dry basalts and basalts saturated with salt water due to ocean intrusion. Given the expecting layering in these sites, interpretation should be much easier: dry versus water saturated basalts or scoria. Windward highlands sites have been studied mainly to measure the thickness of soils, which is a key parameter to quantify storage in the water cycle and water fluw as a recharge to deep aquifers. Mid-slope sites have only been investigated on San Cristobal because the perched aquifers depth is compatible with the penetration depth of seismic-refraction method (several tens of meters). Indeed the emergence of springs indicates the existence of shallow groundwater on San Cristobal [Pryet et al., 2012a; Dominguez, 2016]. On the contrary, Santa Cruz Island presents a buried perched aquifer, identified by helicopter borne geophysical method at more than 100 meters depth [d'Ozouville et al., 2008; Auken et al., 2009; Pryet et al., 2012a], a depth that cannot be reached with sledge-hammer source.

Let now detailed the site location and the layout for both islands. SZ1 is very close to the seashore (Figure 1), on a $6.5 \mathrm{~m}$ high cliff. The seismic line was deployed perpendicular to the seashore. SZ2 is an urban site; the line follows the drawing of a future road that leads to a residential area. As observed in the picture of figure 2, the road is without asphalt. The line was also deployed perpendicularly to the seashore. SZ3 is located in a pasture with flourishing vegetation. This longest investigated line was deployed south-eastward along the steepest slope. During acquisition, weather was foggy and rainy on this last site. SC1 is a San Cristobal site, the nearest from the coast. The line was deployed parallel to the seashore. SC2 is an urban site on a road without asphalt, the line was 
deployed perpendicularly to the seashore. SC3 is close to the airport and to a scoria cone on which an open-pit mine is settled. Figure 3 presents a detailed map of windward mid-slope sites on San Cristobal (SC4 and SC5). SC4 is located downstream of a major water catchment of the island (Cerro Gato water catchment) and near a perennial stream of the same name. An outcrop of pyroclastic material has been described just above the seismic layout [Izquierdo et al., 2015]. SC5 is located on a watershed beside the one of SC4 (Figure $3 b$ and $c$ ). The seismic line has been deployed near a temporary river-bed. We will discuss further the implication of the mid-slope sites locations in terms of velocities in section 3.2. SC6 is on the same watershed than SC4 but in the top of it (altitude around $600 \mathrm{~m}$ ).

Table 1 - Description of sites investigated by seismic-refraction on Santa Cruz and San Cristobal islands

\begin{tabular}{|c|c|c|c|c|c|}
\hline ISLAND & SITES & $\begin{array}{l}\text { ALTITUDE } \\
\text { m a.s.I. }\end{array}$ & $\begin{array}{l}\text { DISTANCE } \\
\text { TO SEA m }\end{array}$ & $\begin{array}{l}\text { LOCATION } \\
\text { TYPE }\end{array}$ & DESCRIPTION \\
\hline \multirow{3}{*}{ 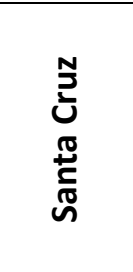 } & SZ1 & 6.5 & 20 & Coastal & $\begin{array}{l}\text { Perpendicular to seashore, on a } 6.5 \mathrm{~m} \text { high } \\
\text { cliff, basaltic lava flow without soil }\end{array}$ \\
\hline & SZ2 & 20 & 1495 & Coastal & Compact soil with scoria deposits \\
\hline & SZ3 & 393 & 7950 & Highlands & $\begin{array}{l}\text { Thick clayed soil layer with abundant } \\
\text { vegetation, humid condition for acquisition }\end{array}$ \\
\hline \multirow{6}{*}{ 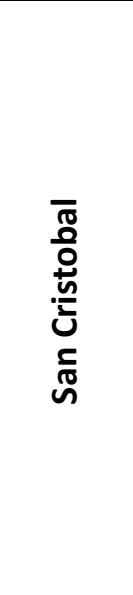 } & SC1 & 1 & 135 & Coastal & $\begin{array}{l}\text { Parallel to seashore, compact soil with } \\
\text { scoria debris (probably substratum is scoria) }\end{array}$ \\
\hline & SC2 & 8 & 350 & Coastal & $\begin{array}{l}\text { Compact soil with rock debris (the } \\
\text { substratum is probably basaltic rock) }\end{array}$ \\
\hline & SC3 & 10 & 915 & Coastal & $\begin{array}{l}\text { Close to a scoria cone (red mine), compact } \\
\text { soil with debris (the substratum is probably } \\
\text { scoria deposit) }\end{array}$ \\
\hline & SC4 & 160 & 1295 & Mid-slope & $\begin{array}{l}\text { Soil and weathered basalt, near a } \\
\text { pyroclastic outcrop }\end{array}$ \\
\hline & SC5 & 230 & 1790 & Mid-slope & Silty to clay soil \\
\hline & SC6 & 590 & 3870 & Highlands & Clayed soil (more than $4 \mathrm{~m}$ of thickness) \\
\hline
\end{tabular}


As far as waves are generated by a sound source and travel across a layered media, different processes occur: wave can be diffracted, reflected or refracted on interfaces. Seismic-refraction methods measure the shortest time of a compressional wave to travel down from the source, through the ground, and back up to sensors placed on the land surface. By measuring the travel times of the sound wave and applying the Snell-Descartes's law that governs the propagation of sound, the geometry and characteristics of the subsurface geology and/or hydrogeology can be inferred. Therefore, field data consist of measured distances and seismic travel times. From this timedistance information, velocity variations and depths to individual layers can be calculated and modelled.

The seismic-refraction survey carried out on Galapagos Islands involves a total of 9 lines. Figure 4 describes the layout used on Santa Cruz (SZ) and San Cristobal (SC) sites. Each line was shot in both forward and reverse order. The sound source is a $4 \mathrm{~kg}$ sledge-hammer striking a Teflon plate. The shot points (SP on Figure 4) are spread on the lines with minimum 4 end-off and 1 central shots. 24 geophones of natural frequency of $10 \mathrm{~Hz}$ are regularly spread on the lines and measure the wave acceleration in the vertical direction. The distance between two geophones (inter-trace IT on figure 4) varies between 1 and $5 \mathrm{~m}$, depending on the studied site. Table 2 summarizes the distances and acquisition parameters used for each site. No frequency filters were applied during data acquisition. Objectives were different according to the sites. For the coastal ones, the objective is to visualize the interface between dry and water saturated rocks having the visual control of the sea level. We know that $\mathrm{P}$-wave velocities are not sensitive to varying salt content of the groundwater, however as soon as we are closed to the sea shore we can interpolate this interface as the top of the salty wedge. The objective in highland site (SZ3) is to estimate the soil thickness and the weathered basalt properties for highland sites, thus a longer line was used for SZ3.At San Cristobal sites, we had the experience of Santa Cruz experiments made 2 years before. In addition targets were shallower, thus long lines were not useful. As a consequence, we used the same layout with a line length of about $100 \mathrm{~m}$ and a $2 \mathrm{~m}$ inter-trace for all the sites on San Cristobal. The same layout allows us to compare results from one site to another in terms of depth penetration and P-wave velocities.

Table 2 - Layout description of seismic-refraction survey on Santa Cruz and San Cristobal islands

\begin{tabular}{|c|c|c|c|c|c|c|c|}
\hline ISLAND & SITES & $\begin{array}{c}\text { geophone } \\
\text { spacing } \\
\text { (m) }\end{array}$ & $\begin{array}{c}\text { Seismic } \\
\text { spread } \\
\text { (m) }\end{array}$ & Geophones & $\begin{array}{l}\text { Strike } \\
\text { bases }\end{array}$ & Acquisition system & $\begin{array}{c}\text { Acquisition } \\
\text { time / } \\
\text { sample } \\
\text { interval } \\
\text { (ms) }\end{array}$ \\
\hline \multirow{3}{*}{$\underset{\substack{\mathbb{N}}}{\stackrel{N}{N}}$} & SZ1 & 1 & 33 & $1 \mathrm{C}-10 \mathrm{~Hz}$ & 5 & DAQLINK III & $500 / 0.5$ \\
\hline & SZ2 & 2 & 66 & $1 \mathrm{C}-10 \mathrm{~Hz}$ & 5 & DAQLINK III & $500 / 0.5$ \\
\hline & SZ3 & 5 & 165 & $1 \mathrm{C}-10 \mathrm{~Hz}$ & 5 & DAQLINK III & $500 / 0.5$ \\
\hline \multirow{3}{*}{$\begin{array}{l}\bar{\pi} \\
\frac{0}{0} \\
\frac{\hbar}{2} \\
\vdots \\
\frac{1}{\pi} \\
n\end{array}$} & SC1 & 2 & 96 & $1 \mathrm{C}-10 \mathrm{~Hz}$ & 9 & $\begin{array}{c}\text { GEODE } \\
\text { GEOMETRICS }\end{array}$ & $500 / 0.5$ \\
\hline & SC2 & 2 & 96 & $1 \mathrm{C}-10 \mathrm{~Hz}$ & 9 & $\begin{array}{c}\text { GEODE } \\
\text { GEOMETRICS }\end{array}$ & $500 / 0.5$ \\
\hline & SC3 & 2 & 96 & $1 \mathrm{C}-10 \mathrm{~Hz}$ & 9 & $\begin{array}{c}\text { GEODE } \\
\text { GEOMETRICS }\end{array}$ & $500 / 0.5$ \\
\hline
\end{tabular}




\begin{tabular}{|c|c|c|c|c|c|c|c|}
\hline & SC4 & 2 & 96 & $1 \mathrm{C}-10 \mathrm{~Hz}$ & 9 & $\begin{array}{c}\text { GEODE } \\
\text { GEOMETRICS }\end{array}$ & $500 / 0.5$ \\
\cline { 2 - 7 } & SC5 & 2 & 96 & $1 \mathrm{C}-10 \mathrm{~Hz}$ & 9 & $\begin{array}{c}\text { GEODE } \\
\text { GEOMETRICS }\end{array}$ & $500 / 0.5$ \\
\cline { 2 - 7 } & SC6 & 2 & 96 & $1 \mathrm{C}-10 \mathrm{~Hz}$ & 9 & $\begin{array}{c}\text { GEODE } \\
\text { GEOMETRICS }\end{array}$ & $500 / 0.5$ \\
\hline
\end{tabular}

195

196

197

198

199

200

201

202

203

204

205

206

207

208

209

210

211

212

213

214

215

216

217

218

219

220

221

222

223

224

225

226

227

228

Samples shot gather of the raw data is given in Figure 5. Trace normalized amplitudes are used for display purpose. The data show good quality where first arrival refracted waves are easily identified. General workflow of seismic-refraction processing is presented on Figure 6. Data were analyzed using the software programs Pickwin (ver 5.1.1.2) and Plotrefa (ver 3.0.0.6) from the SeisImager software package developed by Geometrics Inc. The first step consists in picking first break arrivals of each shot point ( 5 for Santa Cruz sites and 9 for San Cristobal sites). It corresponds to P-wave arrivals. The picking was performed manually (Figure 6.1) using Pickwin. Then arrival times are plotted against source-to-geophone distances, which results in time-distance or traveltimes curves (Figure 6.2). The tomographic method using Plotrefa [Zhang \& Toksoz, 1998] involves the creation of an initial velocity model. Four parameters are required: the depth to top of the lowest layer, the minimum and maximum velocities and the number of layers. According geophone spacing, depth to top of the lowest layer is equal to 10, 20 or 40 meters (respectively for 1, 2 and 5 meters geophone spacing). Minimum and maximum velocities are fixed from the traveltimes curves, adding $30 \%$ for the maximum value. Generally, these values are set to $300 \mathrm{~m} / \mathrm{s}$ (propagation of the sound in air) and $3000 \mathrm{~m} / \mathrm{s}$, respectively. The number of layers is always fixed to 20 . Then, the tomographic method involves iteratively tracing rays through the model, comparing the calculated travel times to the measured travel times, modifying the model, and repeating the process until the difference between calculated and measured times is minimized.

At the end of the tomography process, a global Root Mean Square (RMS) error is calculated, integrating all errors between calculated and measured traveltimes in a least square meaning. This parameter assesses the quality of the workflow. Table 3 presents the final RMS errors obtained after the tomography processing of the nine studied profiles. The final RMS errors lie between 0 and $3 \mathrm{~ms}$ for most of the profiles (SZ1, SZ2, SC1, SC2, SC3, SC4 and SC5). Profiles SZ3 and SC6 show increased RMS errors, which can be related to poorer data quality caused by worse acquisition conditions (bad coupling due to wet clayey soils for these highland sites) compared to the other profiles.Moreover, RMS errors calculated for Santa Cruz sites are higher than the ones for San Cristobal. This can be consequence of the number of shot points : 5 for Santa Cruz and 9 for San Cristobal leading to a better convergence.

Table 3 - Mean RMS errors obtained for the nine profiles after the tomography process. These values show that the models fit our travel time data well.

\begin{tabular}{|c|c|c|c|c|c|c|c|c|c|}
\hline Site & SZ1 & SZ2 & SZ3 & SC1 & SC2 & SC3 & SC4 & SC5 & SC6 \\
\hline $\begin{array}{c}\text { RMS error } \\
(\mathrm{ms})\end{array}$ & 1.024 & 2.365 & 3.757 & 0.864 & 0.262 & 0.966 & 0.836 & 1.104 & 3.846 \\
\hline
\end{tabular}

The final cell size of the tomography model depends on the geophone spacing for the horizontal component and on the resolution during raytracing processing for the vertical one. The vertical 
resolution is globally equal to the half of the horizontal one. Table 4 summarizes the cell size obtained for the studied profiles according to the geophone spacing and also the total number of cells.

Table 4 - Horizontal ( $X$ size) and vertical ( $\mathrm{Z}$ size) components of the tomography cell for each profile. The total number of cells is also mentioned.

\begin{tabular}{|c|c|c|c|c|c|c|c|c|c|}
\hline Site & SZ1 & SZ2 & SZ3 & SC1 & SC2 & SC3 & SC4 & SC5 & SC6 \\
\hline $\begin{array}{c}\text { X size } \\
(\mathrm{m})\end{array}$ & 1 & 2 & 5 & 2 & 2 & 2 & 2 & 2 & 2 \\
\hline $\begin{array}{c}\text { Z size } \\
(\mathrm{m})\end{array}$ & 0.5 & 1 & 2.5 & 1 & 1 & 1 & 1 & 1 & 1 \\
\hline $\begin{array}{c}\text { Number } \\
\text { of cells }\end{array}$ & 486 & 630 & 517 & 432 & 432 & 432 & 432 & 432 & 432 \\
\hline
\end{tabular}

Using as example the SC2 profile, figure 6 provides the reliability of raytracing and the tomography processing of our study case. Observed and calculated traveltimes are very closed (Figure 6a) and raytracing is coherent (Figure 6b). Note that we compare the first arrivals only for the times that are inside the profiles. Indeed cells that are off sides are not covered by enough rays and then cannot be solved. Final RMS error is low, less than $1 \mathrm{~ms}$, decreasing sharply just after one iteration (Figure 6c). Assessing the coherence of raytracing allows us to be confident with the penetration depth. Following results have been checked to be reliable in terms of depth.

\section{P-wave tomography results}

Before our results are presented, we want to note once again that seismic-refraction is not the more efficient tool to study the variation of salt content into water. Therefore, we would infer the sea intrusion beneath island only for the coastal sites, where we know that the salty wedge is at the same depth that the groundwater level. Indeed, near the coast, the freshwater layer is very thin with only a few centimetres thick. At other sites, the visible water saturated layers can only be described as groundwater levels.

\subsection{On Santa Cruz Island}

Figure 8 presents the tomography profiles of the three sites investigated on Santa Cruz Island. Resolution in depths and in P-wave velocities is different due to the variable intertrace between geophones. All profiles are shown with a flat surface because we succeed to deploy the different profile without important topographic variations. SZ1 site is located on a cliff $(6.5 \mathrm{~m}$ above the sea level) with a direct visual checking of the seawater level. Outcrops exhibit a massive basaltic lava flow with numerous metric fractures. The velocity profile precisely presents a strong refractor $6.5 \mathrm{~m}$ beneath the ground surface, which corresponds to the sea water level position. A first layer of very low velocity (around $500 \mathrm{~m} / \mathrm{s}$ ) is very thin (about 2 meters width) and corresponds to unconsolidated material. The second and third layers of velocity respectively around $1600 \mathrm{~m} / \mathrm{s}$ and $2400 \mathrm{~m} / \mathrm{s}$, are separated by an interface located at the sea water level position. Thus, these layers correspond 
respectively to dry and seawater saturated layers. This site allows the possibility to check the application of seismic-refraction to visualize ocean intrusion.

On SZ2 profile, the seawater level is also visible, $20 \mathrm{~m}$ deep beneath the ground surface, which corresponds to the altitude of the site. We have access to more information than for SZ1 concerning the velocity layering thanks to a higher penetration depth (due to longer seismic line). The thickness of the first layer of low velocity $(500 \mathrm{~m} / \mathrm{s})$ is about 2 meters and it could correspond to embankment. Indeed, the seismic line of SZ2 has been deployed on a future road. The second very low velocity layer (around $1000 \mathrm{~m} / \mathrm{s}$ ) is several meters thick with a lateral variation from 2 to 6 meters thick. It could correspond to burden unconsolidated material. Beneath this layer we find again a low velocity layer with a magnitude similar to the one obtained on SZ1 (around $1600 \mathrm{~m} / \mathrm{s}$ ), which is considered as a dry layer. Finally, beneath the seawater level, we identify a water saturated layer with higher velocity $(2400 \mathrm{~m} / \mathrm{s})$ which can be the top of the salty wedge.

The profile obtained on SZ3 site is the longest one of the present study. Distance between geophones is 5 meters, and the total spread is about $200 \mathrm{~m}$. Due to the poor signal to noise ratio, the identification of the first break is more difficult in this profile. The global RMS error is quite high (Table 3: less than $4 \mathrm{~ms}$ actually).However, results are coherent with the other ones and the penetration depth is about $50 \mathrm{~m}$. A first velocity layer with P-wave velocity around $350 \mathrm{~m} / \mathrm{s}$ is observed from the surface to about $15 \mathrm{~m}$ deep. This velocity value is closed to the one of P-waves into the air $(340 \mathrm{~m} / \mathrm{s})$, that is why we assume that this first layer is an unconsolidated one.. Beneath this very low velocity layer, a medium of about $15 \mathrm{~m}$ deep with a velocity around $1500 \mathrm{~m} / \mathrm{s}$ is visible. This layer covers another velocity layer with a positive gradient according the depth, from $1500 \mathrm{~m} / \mathrm{s}$ to $2400 \mathrm{~m} / \mathrm{s}$ at the deepest parts of the profile. Mostly In the western part of the profile, beneath about 30-40 m depth we find a high velocity layer (about $2400 \mathrm{~m} / \mathrm{s}$ ). Regarding results obtained on SZ1 and SZ2 we interpreted it as a water saturated layer. But the resolution is too low to be sure on this last interpretation.

To conclude on Santa Cruz, we identified three layers, from top to bottom: unconsolidated material with very low velocities near the surface, a dry layer associated to low velocities (around $1600 \mathrm{~m} / \mathrm{s}$ ) and a water saturated one associated to high velocities $(2400 \mathrm{~m} / \mathrm{s})$. The last one can be easily identified at SZ1 and SZ2. Note that, even for the high velocity layer, the absolute velocity values remain low. It is probably because of the high degree of fracturing in the basaltic rocks, which is in agreement with the outcrop observations made on the cliff beneath SZ1. Compressive acoustic waves are very sensitive to fractures, and their velocity decrease sharply with increasing fracture density.

\subsection{On San Cristobal island}

Figures 9 and 10 present the P-waves velocity models obtained respectively at the three coastal sites and at the three mid-slope and highland sites on San Cristobal Island. Similarly to Santa Cruz, three velocity layers could be identified from the six profiles as follows:

- A very low velocity layer (around $500 \mathrm{~m} / \mathrm{s}$ ) interpreted as unconsolidated material

- A low velocity layer (between 1400 and $1700 \mathrm{~m} / \mathrm{s}$ ) interpreted as dry rocks 
- A high velocity layer (between 2400 and $2700 \mathrm{~m} / \mathrm{s}$ ) interpreted as water saturated rocks, note that water can be salty or fresh depending of the location, coastal or highland respectively.

San Cristobal coastal sites ( $\mathrm{SC} 1, \mathrm{SC} 2, \mathrm{SC} 3$ ) have a flat topography. The velocity models of these sites present a thin unconsolidated layer near the surface (Figure 9). The thickness of this layer is less than 1 meter for SC2 and SC3 and about 2 meters for SC1. The ocean intrusion is visible for the three coastal sites at sea level. As SC1 is the nearest site from the seashore, the saturation interface is a strong refractor and could hide a limit of alteration located just above. Thus the first layer with low velocity is probably in fact a mixed layer composed with unconsolidated material and unsaturated rocks. This can explain its relative high thickness according to other coastal sites. Once again, at this site the sea water intrusion appears beneath the real sea level. Moreover, as SC1 is the nearest site from the seashore, it could be due to a tide effect. SC2 presents the typical layering made with a very low velocity layer (less than $500 \mathrm{~m} / \mathrm{s}$ ) of unconsolidated material, a low velocity one (around 1600 $\mathrm{m} / \mathrm{s}$ ) of unsaturated fractured basalts and a high velocity one (around $2700 \mathrm{~m} / \mathrm{s}$ ) associated to a water saturated layer. The saturation interface is shown at sea level as expected. SC3 presents the same layering than $\mathrm{SC} 2$ with a smoother transition between water saturated and unsaturated layers. Moreover, the velocity of the water saturated layer is lower for SC3 profile (around $2400 \mathrm{~m} / \mathrm{s}$ ) than for the SC1 and SC2 ones(around $2700 \mathrm{~m} / \mathrm{s}$ ).

Results obtained for mid-slope and highland sites are contrasting (Figure 10). First, these profiles present a topography (more than $15 \%$ slope for SC5 and SC6 for instance). The velocity profile deduced at the highest site (SC6) presents only one very low velocity layer associated to soil, with one sublimit inside, at about $30 \mathrm{~m}$ depth. Site SC5 is located at a mid-slope on the windward side as well. The first layer is thinner (about 3.5 meters). This soil layer is above a distinguishable low velocity layer (around $1300 \mathrm{~m} / \mathrm{s}$ ), which could be associated to dry material according to the results obtained at the coast. In the northern part of the profile, a layer with higher velocity $(2000 \mathrm{~m} / \mathrm{s})$ is recognisable in depth. It could be the top of a partially saturated level. The fully saturated layer would be located below.

Finally, tomography profile obtained on SC4 is the most interesting one. From a hydrological point of view, this site is located downstream of a major perennial spring of the island (Cerro Gato spring) and near a stream fed from this spring. The spatial configuration of seismic layout regarding the hydrological aspects is presented on figure 3. The first soil layer is about $3 \mathrm{~m}$ deep, comparable to SC5. Beneath, the second velocity layer of about $10 \mathrm{~m}$ width corresponds probably to an unsaturated layer. But on the contrary to SC5, there is clearly a third layer on the bottom part of the profile with high velocity (about $2400 \mathrm{~m} / \mathrm{s}$ ). This layer might correspond to a saturated material. The velocity value is indeed similar to the corresponding one measured on SC3. 


\subsection{Geological and hydrogeological interpretations}

From an acoustic velocity point of view, both islands present the same layering in the subsurface (i.e. in the first dozen of meters): an unconsolidated level near the surface with very low velocities associated to unconsolidated material, a low velocity layer associated to dry volcanic material and a high velocity level in depth, associated to water saturated volcanic material.

The first layer located very close to the surface could be interpreted as debris at the coast (embankment or desegregated volcanic material) and clayed soil in the highlands. For instance, on SC6, It could be interpreted as a thick soil above highly weathered volcanic material. Indeed, at the end of the formation of San Cristobal, the island was partially covered by pyroclastic deposits according to Geist et al. [1986]. The alteration of such material may have formed the soil we see on the seismic-refraction data. Coastal sites with visual controls on the geology and the saturation interface allow the quantification and calibration of velocity in basalts, while it is water saturated or not. This is the case of SZ1 and SC1, providing basaltic lava flows on outcrops. Variations in velocities according to these calibration data supply new information. For instance, the saturated layers of SC3 and SC4 have lower velocities than the saturated layers of SC1 $(2400-2500 \mathrm{~m} / \mathrm{s}$ against $2700 \mathrm{~m} / \mathrm{s})$. It could be explain by the nature of the basement, SC3 and SC4 are very close to a scoria deposit cone where pyroclastic deposits can be observed around the areas (Figure 3). Now, if we compare both islands, on Santa Cruz, the velocities respectively in dry and water saturated basalts are around 1400 and $2400 \mathrm{~m} / \mathrm{s}$ whereas on San Cristobal they are 1400 and $2700 \mathrm{~m} / \mathrm{s}$, respectively. The velocity difference between the two islands could be explained by the elder of each one. Indeed, as mentioned in the introduction, Santa Cruz is younger than San Cristobal and probably their fractures in basalts are fresher and not filled with other material (able to reduce the porosity). On San Cristobal, cooling fractures should be filled by alteration material or oversaturated fluid precipitation.

From a hydrogeological point of view, SC4 shows important results. The existence of a high velocity layer related to a water saturated level is clear. This could be interpreted as an aquifer.. This result is in accordance with previous helicopter-borne geophysical study, which reveals that both islands have prominent low resistivity layers in the range of 30-130 ohm.m beneath the windward highlands [d'Ozouville et al., 2008b; Auken et al., 2009; Pryet et al., 2011b, 2012a]. These resistivity values are of particular interest because they are characteristic of basalt saturated with water on other islands [Lienert, 1991; Descloitres et al., 1997; Krivochieva and Chouteau, 2003; Vittecoq et al., 2014 and 2015]. The Cerro Gato stream is located $80 \mathrm{~m}$ away from the left limit of the profile (A). This layer could be a saturated layer that corresponds to a freshwater perched aquifer supplying the hydrographic network. The water table is quite horizontal with a very low slope ( $2^{\circ}$ towards the SW). corresponding to the direction of the topography. The orientation suggests that the aquifer is fed by the stream. Compared to SC4, profile obtained on SC5 does not show any fully water saturated layer. Figure 3 shows that SC5 is near from a temporary river bed. As we investigated sites during the end of the hot season (in July), the river bed was dry. Consequently groundwater could be at deeper levels and not supplied by surface network at this period of the year. 
A key point to build quantitative hydrogeological model is the assessment of porosity of the different geological layers, porosity being the storage capacity of an unconfined aquifer. Acoustic velocities associated with effective medium modelling can bridge the gap between the geological lithology description and the porosity assessment at field scale [Adelinet et al., 2011; Adelinet \& Le Ravalec, 2015]. Indeed, P-waves (and also of course S-waves) are very sensitive to the rock heterogeneity, such as grain contacts, pores, cracks or fractures, and Galapagos volcanic islands are a highly fractured medium. However, according to the scale and to the geophysical method, we do not investigate the same size of heterogeneity, it depends on the wavelength. In our case, due to the acquisition layout (sledge-hammer source), we have a central frequency of about $100 \mathrm{~Hz}$ [Keiswetter and Steeples, 1995; Feroci et al., 2000]. Given an average P-wave velocity of 2000 m/s, it results in an average wavelength of $20 \mathrm{~m}$ for our seismic experiment. According to the standard test method for the determination of velocities [ASTM D2845-08, 2008], the wavelength should be at least three times the average heterogeneity size. Reversely, that means that our method provides velocities affected by heterogeneities of several meters length (fractures specially). Moreover, considering that seismic resolution is defined by a rule of thumb as the quarter of the wavelength, it means that our acquisition set-up would not be accurate to image anything with a thickness smaller than 5 meters.

Besides, as seismic data reveal the existence of saturated layer in depth, we have to discuss another frequency effect on elastic properties of volcanic material. Indeed, at low frequency, the fluid pressure is constant and unaffected by the seismic waves, it is the drained regime. At higher frequencies, the assumption of fluid pressure equilibrium becomes invalid, the fluid pressure is locally uniform but changes when the waves pass through; the regime is called the undrained regime. Both drained and undrained regimes are relevant of the poroelasticity theory [Gassmann, 1951; Biot, 1956; Murphy, 1986]. According Cleary [1978], the cut-off frequency $\left(f_{c}\right)$ between the drained and the undrained states depends on the rock intrinsic permeability $k\left(m^{2}\right)$, the drained bulk modulus $K_{d}$ (equal to the dry modulus, $P a$ ), the fluid viscosity $\eta(P a . s)$ and a flow length $L(m)$ as follows:

$f_{c}=\frac{4 \times k \times K_{d}}{\eta \times L^{2}}$

The poroelasticity framework and the associated equations allow calculating the drained saturated moduli from the drained dry ones. To apply such theory we need to know in which frequency range the field experiments are. We can evaluate the cutoff frequency for our investigated sites considering a flow length, $L$, equal to a half wavelength (around 10 meters) and a drained dry bulk modulus around $10 \mathrm{GPa}$. The touchy parameter is the rock intrinsic permeability. At the laboratory scale, andesite basaltic and scoria flows may have the same permeability around $10^{-12} \mathrm{~m}^{2}$ [Saar and Manga, 1999]. We expect that on the field and due to fractures, the permeability is higher. Based on a hydrogeological modelling, Dominguez [2016] provide range between $10^{-9}$ and $10^{-11} \mathrm{~m}^{2}$ for San Cristobal sites, which are in agreement with literature on permeability in highly fractured basalts [Bear, 1972]. Furthermore, Ingrebitsen \& Scholl [1993] provide near surface horizontal permeabilities around $10^{-10} \mathrm{~m}^{2}$ for the Hawaiian Kilauea volcano which is a good analogue for Galapagos islands [Violette et al., 2014]. Now, if we take an average value of $10^{-10} \mathrm{~m}^{2}$ for our field sites, we obtain a cutoff frequency of $0.4 \mathrm{~Hz}$ between the drained regime and the undrained one. This value is lower than the sledge-hammer frequency of $100 \mathrm{~Hz}$ and then validates our poroelastic approach that we will 
describe now, i.e. we will assume that fluid pressure in the saturated basalts is affected by the seismic wave (undrained regime).

Our goal is to relate P-wave velocities to porosity for each investigated site. In an isotropic framework, P-wave velocity (VP) can be written as a function of bulk and shear moduli, respectively noted $\mathrm{K}$ and $\mathrm{G}$, as follow:

$V P=\sqrt{\frac{K+4 / 3 G}{\rho}} \Leftrightarrow K=\rho V P^{2}-4 / 3 G$

Where $\rho$ is the rock bulk density.

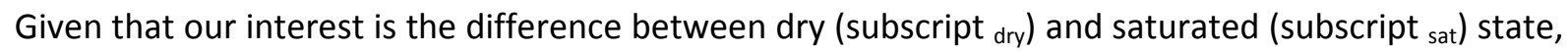
we introduce $\Delta K$ as the difference between the saturated and the dry bulk modulus:

$\Delta K=K_{\text {sat }}-K_{d r y}=\rho_{\text {sat }} V P_{\text {sat }}^{2}-4 / 3 G_{s a t}-\rho_{d r y} V P_{d r y}^{2}+4 / 3 G_{d r y}$

Considering that we remain in the poroelasticity framework, we can use the first equation of BiotGassmann, which announces that the saturated shear moduli is equal to the dry one. So:

$\Delta K=\rho_{\text {sat }} V P_{\text {sat }}^{2}-\rho_{d r y} V P_{d r y}^{2}$

So, the variation in bulk moduli is directly related to the variation of P-wave velocity according saturation state. Velocities in dry and saturated medium are available on sites where a water table is visible (sea water level or perched aquifer), i.e. sites SZ1, SZ2, SZ3, SC1, SC2, SC3 and SC4.

Moreover, density is related to the porosity $\emptyset$ according the saturation state by:

$\rho_{\text {sat }}=(1-\varnothing) \rho_{0}+\emptyset \rho_{w}$

$\rho_{\text {dry }}=(1-\emptyset) \rho_{0}$

Where $\rho_{0}, \rho_{d r y}$ and $\rho_{\text {sat }}$ are the densities of the matrix, the dry rock and the saturated rock respectively.

Then, $\Delta \mathrm{K}$ can be expressed as a function of porosity and variation in velocities (noted $\Delta K_{V P}$ due to the use of P-wave velocities):

$\Delta K_{V P}(\varnothing)=(1-\emptyset) \rho_{0}\left(V P_{s a t}^{2}-V P_{d r y}^{2}\right)+\emptyset \rho_{w} V P_{s a t}{ }^{2}$

Besides, the second Biot-Gassmann equation relates the saturated and the dry bulk moduli as:

$K_{s a t}=K_{d r y}+\frac{\beta^{2} K_{f}}{\emptyset+(\beta-\emptyset) \frac{K_{f}}{K_{0}}}$

Where $\beta$ is the Biot coefficient, $K_{f}$ and $K_{0}$ the water and matrix bulk modulus respectively. Besides, the Biot coefficient is equal to:

$\beta=1-\frac{K_{d r y}}{K_{0}}$ 
Then the variation in bulk modulus can be expressed in a different way as a function of porosity (noted $\Delta K_{B G}$ due to the use of Biot-Gassmann theory):

$\Delta K_{B G}(\varnothing)=\frac{\beta^{2} K_{f}}{\emptyset+(\beta-\emptyset) \frac{K_{f}}{K_{0}}}$

No assumption is made on nature of porosity inclusions in the Biot-Gassmann equations: it is a macroscopic approach using the total pore space. We keep in mind that for water catchment the effective porosity is need. Our approach could be coupled with a structural geological field work to analyse precisely the fracture network. The next step would be to calculate the porosity proportion identified as crack porosity and introduce it in the effective medium modelling.

Finally from (7) and (10) we have a relationship between the difference of P-wave velocities, between saturated and dry states, and the porosity. The leading idea consists in minimizing a given objective function to determine the porosity. The objective function $J$ is define as:

$J(\varnothing)=\left(1-\frac{\Delta K_{V P}(\varnothing)^{2}}{\Delta K_{B G}(\varnothing)^{2}}\right)^{2}$

It is a one-term function, which quantifies the data mismatch in a least-squares sense. The minimization process is iterative; the process is repeated until the objective function is small enough. The optimization parameter is the porosity. Other parameters remain constant (Table 5), especially the Biot coefficient which is fixed to 1 in a first approach, i.e. we assume that $K_{d r y}$ is much smaller than $K_{0}$. Matrix modulus is taken equal to $25.6 \mathrm{GPa}$ from experimental data performed in laboratory on Santa Cruz basalts as both islands present the same general lithology [Loaiza, 2012].

Table $\underline{3} 5$ - Constant parameters

\begin{tabular}{|c|c|c|}
\hline $\begin{array}{c}\rho_{-} \text {matrix } \\
(\mathrm{kg} / \mathrm{L})\end{array}$ & $\begin{array}{c}\rho_{-} \text {water } \\
(\mathrm{kg} / \mathrm{L})\end{array}$ & $\begin{array}{c}\text { K_water } \\
(\mathrm{GPa})\end{array}$ \\
\hline 2.7 & 1 & 2.25 \\
\hline
\end{tabular}

Table6 summarizes input data (dry and saturated P-wave velocities) and output data (porosities) for the different sites on which we have both velocities. Note that SC3 and SC4 are respectively close to scoria cone and pyroclastic debris.

Table $\underline{46}$ - Input P-wave velocities and calculated porosity with constant Biot coefficient

\begin{tabular}{|l|l|l|l|l|l|l|l|}
\hline sites & SZ1 & SZ2 & SZ3 & SC1 & SC2 & SC3 & SC4 \\
\hline VP_sat (km/s) & 2.39 & 2.33 & 2.39 & 2.69 & 2.72 & 2.53 & 2.43 \\
\hline VP_dry (km/s) & 1.30 & 1.36 & 1.35 & 1.34 & 1.38 & 1.33 & 1.38 \\
\hline J evaluations & 10 & 11 & 9 & 13 & 13 & 11 & 10 \\
\hline J minima & $1.44 \mathrm{E}-13$ & $3.02 \mathrm{E}-12$ & $7.12 \mathrm{E}-11$ & $2.12 \mathrm{E}-11$ & $4.31 \mathrm{E}-11$ & $1.25 \mathrm{E}-10$ & $7.62 \mathrm{E}-12$ \\
\hline $\begin{array}{l}\text { inverted } \\
\text { porosity }\end{array}$ & $\mathbf{0 . 1 5}$ & $\mathbf{0 . 1 8}$ & $\mathbf{0 . 1 6}$ & $\mathbf{0 . 0 8}$ & $\mathbf{0 . 0 8}$ & $\mathbf{0 . 1 1}$ & $\mathbf{0 . 1 5}$ \\
\hline
\end{tabular}

Galapagos lava flows are described as riches in vacuoles due to gas trapping inside magma [Loaiza, 2012]. Inverted porosities are in range of acceptable values for such effusive volcanic material 
[Adelinet, 2010; Schaefer et al., 2015; Siratovich et al., 2014]. Laboratory porosity measurements made on fresh Santa Cruz basalts provide values between 10 and 12 \% [Loaiza, 2012]. We can classify results of table 4 according three porosity facies: low porosity on basaltic San Cristobal sites (SC1 and SC2), intermediate porosity for scoria San Cristobal coastal site (SC3), and high porosity of Santa Cruz sites and mid-slope San Cristobal pyroclastic site(SZ1, SZ2, SZ3 and SC4). According to geological interpretation made before, the lowest porosity is associated with coastal basaltic sites (SC1 and SC2).

In order to discuss much precisely the absolute values of porosity we need to have a sensitivity approach on the parameters introduced in the objective function. We identified two major sinks of errors on porosity computations: the values of Biot coefficient arbitrary fixed to 1 and the matrix bulk modulus, which has been chosen from experimental laboratory data. Thus we perform simulations with different couples of Biot coefficient and matrix bulk modulus whereas other parameters remaining constant. We choose velocity values of site SC1 as representatives of good quality data. Figure 11 presents the sensitivity results. The range of variation for tested parameters is $0.6-1$ for Biot coefficient and $10-50 \mathrm{GPa}$ for matrix bulk modulus in order to see the influence of both parameters on porosity. The computed porosity range is between 0 (computed for very low matrix bulk modulus, not realistic with volcanic rocks) and 0.17 . The dependence of porosity with bulk modulus is the highest for Biot coefficient equal to 1. For realistic values of Biot coefficient and matrix bulk modulus (respectively 0.8-1 range and 20-40 GPa range, white square on Figure 9), the porosity is more dependent on the variation in Biot coefficient than on the matrix bulk modulus. Note that porosity increases with higher values of bulk modulus, which could be incoherent at the first glad. However, in this sensitivity approach the macroscopic field velocities remain constant (data from SC1 profile). Then, if the matrix is stiffer (high bulk modulus), the effective medium modelling needs to increase the porosity in order to fit with velocities which remains the same all over the tested values of bulk modulus.

In order to reduce this range of variability we introduce a variable Biot coefficient into our inverse modelling. For that we need to express the dry bulk modulus ( $K_{d r y}$ of eq. 9 ) as a function of known parameters. As we have only measure P-wave velocities on field, we assume a constant Poisson's ratio (noted $v$ ) which is a more stable coefficient. In this case the dry bulk modulus $\left(K_{\text {dry }}\right)$ is expressed from dry P-wave velocity and $\mathrm{v}$ :

$K_{d r y}=\frac{1+v}{3(1-v)} \times \rho_{\mathrm{dry}} \times \mathrm{VP}_{\mathrm{dry}}{ }^{2}$

Injecting the dependency of $\rho_{\mathrm{dry}}$ with porosity we obtain:

$K_{d r y}=\frac{1+v}{3(1-v)} \times(1-\emptyset) \times \rho_{0} \times \mathrm{VP}_{\mathrm{dry}}^{2}$

We can now reformulate the objective function by introducing the new $K_{\text {dry }}$ expression within the Biot coefficient (eq. 9). Table 7 presents the new porosities calculated from minimization of the new $J$ function and with a Poisson's ratio of 0.25 accordingly with literature data [Schultz, 1995; Adelinet, 2010; Loaiza, 2012]. This table presents also the post-calculation of the Biot coefficient and the $K_{d r y}$ values for each site. 


\begin{tabular}{|l|r|r|r|r|r|r|r|}
\hline sites & SZ1 & \multicolumn{1}{|l|}{ SZ2 } & SZ3 & SC1 & SC2 & SC3 & \multicolumn{1}{l|}{ SC4 } \\
\hline VP_dry (km/s) & 1.30 & 1.36 & 1.35 & 1.34 & 1.38 & 1.33 & 1.38 \\
\hline new_porosity & $\mathbf{0 . 1 1}$ & $\mathbf{0 . 1 4}$ & $\mathbf{0 . 1 2}$ & $\mathbf{0 . 0 5}$ & $\mathbf{0 . 0 5}$ & $\mathbf{0 . 0 8}$ & $\mathbf{0 . 1 1}$ \\
\hline K_dry (GPa) & 2.25 & 2.40 & 2.42 & 2.55 & 2.71 & 2.44 & 2.55 \\
\hline Biot coefficient & 0.91 & 0.91 & 0.91 & 0.90 & 0.89 & 0.90 & 0.90 \\
\hline
\end{tabular}

Inverted porosities are smaller than the previous ones computed with a Biot coefficient equal to 1 , in agreement with the sensitivity approach given in Figure 9. Moreover, the post-processed Biot coefficient is relatively constant between sites, with a mean value of 0.90 and a standard deviation of 0.007 .

542 Finally we plot the porosity in the map dry P-wave velocities versus saturated P-wave velocities 543 (Figure 12) using the last optimization process with variable Biot coefficient. We show three domains. 544 The first one is the low porosity area (porosity less than $8 \%$ ) in which basalts of coastal San Cristobal

545 sites are present (SC1 and SC2). This area is interpreted as the domain of basaltic rocks weakly weathered. The second porosity area concerns intermediate values (between 8 and $13 \%$ ) in which SZ1, SZ3, SC3 and SC4 are present. Due to the presence of SC3 and SC4, we interpret this area as the domain of scoria and pyroclasts. The limit between the two areas could also be a limit of weathering: a weathered basaltic lava flow could have the same porosity. A third domain is also recognizable with higher porosity (more than $13 \%$ ). It could be attributed to very weathered or fractured rocks. The lowest computed porosity is the one of SC1 and SC2 with $5 \%$. It is the site closest the seashore with evidence of basaltic lava flows as underground. The most similar site on Santa Cruz is SZ1 with a porosity of $11 \%$. The difference between porosities should rely once again on the age of the islands. Lava flows on San Cristobal are older than on Santa Cruz. Porosity had time to be filled with secondary material, especially into the pores and fractures. On Figure 12, we notice that all the three sites of Santa Cruz are close and the highest value of porosity is obtained for SZ2 (14\%) which is the closest to the coast. Then we can assume that lower velocities recorded on Santa Cruz interpreted as high porosity values could be due to the high degree of fracturing of the young basaltic lava flows forming this island.

\section{Conclusion}

Seismic-refraction has been successfully used on Santa Cruz and San Cristobal Islands. It was a challenge to obtain acoustic information in the subsurface in such complex structural area. Moreover, penetration depths are enough to image different hydrogeological structures, salted wedge and a freshwater perched aquifer especially. Even if obtained P-wave velocity values obtained remains low we are able to distinguish different velocity layers and interpret them in terms of water saturation state. One step further should be the acquisition or the specific processing [Foti et al., 2003; Williams et al., 2003; Grelle \& Guadagno, 2009; Pasquet et al., 2015; Uhlemann et al., 2016] to have access to shear-wave tomography, specially using the surface wave processing (Multi-Channel Analysis of Surface Waves, [Park et al., 1999]). Nevertheless, our study provides the mapping of low and high velocity layers in different geological context (basaltic lava flow or pyroclastic deposits) and at different altitudes. We went a step further by interpreting differences between dry and watersaturated P-wave velocities in terms of porosity thanks to the poroelasticity theory. From this work, 
574 absolute porosity values could be attributed to Galapagos subsurface material according elevation 575 and geological facies: unweathered and weathered basaltic lava flows, scoria and pyroclast materials.

576 This data could be very helpful in the building of flow models for the Galapagos Islands.

577

578

579

580

581

582

583

584

585

586

587

588

\section{Acknowledgements}

This work is a part of the GIIWS project funding by the ANR-blanc 2010 GIIWS Ref. 601-01. The authors are grateful to the Galápagos National Park Service, the Charles Darwin Foundation, the Municipalities of Santa Cruz and San Cristóbal, and the Consejo de Gobierno del Régimen Especial de Galápagos (CGREG) for local collaborations and logistical support. Christian Domínguez participation was supported by a PhD Scholarship from the Ecuadorian Government through the Secretaría Nacional de Educación Superior, Ciencia y Tecnología (SENESCYT). The helpful comments and corrections from reviewers are gratefully acknowledged. 
590 Adelinet, M., Fortin, J., d'Ozouville, N., \& Violette, S. (2008). The relationship between hydrodynamic 591 properties and weathering of soils derived from volcanic rocks, Galapagos Islands 592 (Ecuador). Environmental geology, 56(1), 45-58.

593 Adelinet, M. (2010). Du terrain au laboratoire, étude des propriétés élastiques du basalte (Doctoral 594 dissertation, Université du Maine).

595 Adelinet, M., Dorbath, C., Le Ravalec, M., Fortin, J., \& Guéguen, Y. (2011). Deriving microstructure 596 and fluid state within the Icelandic crust from the inversion of tomography data. Geophysical 597 research letters, 38(3).

598 Adelinet, M., \& Le Ravalec, M. (2015). Effective medium modeling: How to efficiently infer porosity 599 from seismic data?. Interpretation, 3(4), SAC1-SAC7.

600 Anderson, M. G., \& Burt, T. P. (1978). The role of topography in controlling throughflow 601 generation. Earth Surface Processes, 3(4), 331-344.

602 ASTM D2845-08, (2008). Standard Test Method for Laboratory Determination of Pulse Velocities and 603 Ultrasonic Elastic Constants of Rock, ASTM International, West Conshohocken, PA, 604 2008, www.astm.org

605 Auken, E., Violette, S., d’Ozouville, N., Deffontaines, B., Sørensen, K. I., Viezzoli, A., \& De Marsily, G. 606 (2009). An integrated study of the hydrogeology of volcanic islands using helicopter borne transient 607 electromagnetic: Application in the Galápagos Archipelago. Comptes Rendus Geoscience, 341(10), 608 899-907.

609 Ayers, J. F., \& Vacher, H. L. (1986). Hydrogeology of an atoll island: a conceptual model from detailed 610 study of a Micronesian example. Ground Water, 24(2), 185-198.

611 Banda, E., Dan, J. J., Surin, E., \& Ansorge, J. (1981). Features of crustal structure under the Canary 612 Islands. Earth and Planetary Science Letters, 55(1), 11-24.

613 Bear, J. (1972). Dynamics of fluids in porous media. American Elsevier, New York.

614 Biot, M. A. (1956). Theory of propagation of elastic waves in a fluid-saturated porous solid. II. Higher 615 frequency range. the Journal of the Acoustical Society of America, 28(2), 179-191.

616 Bosshard, E., \& MacFarlane, D. J. (1970). Crustal structure of the western Canary Islands from seismic 617 refraction and gravity data. Journal of Geophysical Research, 75(26), 4901-4918.

618 Bow, C. S. (1979). Geology and petrogeneses of the lavas of Floreana and Santa Cruz Islands: 619 Galápagos Archipelago. Oregon Univ., Eugene (USA).

620 Cleary, M. P. (1978). Elastic and dynamic response regimes of fluid-impregnated solids with diverse 621 microstructures. International Journal of Solids and Structures, 14(10), 795-819. 
Descloitres, M., Ritz, M., Robineau, B., \& Courteaud, M. (1997). Electrical structure beneath the eastern collapsed flank of Piton de la Fournaise volcano, Reunion Island: Implications for the quest for groundwater. Water resources research, 33(1), 13-19.

Domínguez Gonzalez, C. G. (2016). Integrated hydrogeological study of San Cristobal Island, Galapagos. Doctoral dissertation, Ph. D. thesis, Université Pierre et Marie Curie, Paris.

Dominguez Gonzalez, C., Pryet, A., Garcia Vera, M., F., Gonzalez, A., Chaumont, C., Tournebize, J., Villacis, M. J., D'ozouville, N., Violette, S., (2016). Comparison of deep percolation rates below contrasting land covers with a joint canopy and soil model. Journal of Hydrology, 532, 65-79, doi:10.1016/j.jhydrol.2015.11.022

d'Ozouville, N. (2007). Étude du fonctionnement hydrologique dans les îles Galápagos: caractérisation d'un milieu volcanique insulaire et préalable à la gestion de la ressource. Doctoral dissertation, Ph. D. thesis, Université Pierre et Marie Curie, Paris.

d'Ozouville, N., Deffontaines, B., Benveniste, J., Wegmüller, U., Violette, S., \& De Marsily, G. (2008a). DEM generation using ASAR (ENVISAT) for addressing the lack of freshwater ecosystems management, Santa Cruz Island, Galapagos. Remote Sensing of Environment, 112(11), 4131-4147.

d'Ozouville, N., Auken, E., Sorensen, K., Violette, S., De Marsily, G., Deffontaines, B., \& Merlen, G. (2008b). Extensive perched aquifer and structural implications revealed by 3D resistivity mapping in a Galapagos volcano. Earth and Planetary Science Letters, 269(3), 518-522.

Feroci, M., Orlanda, L., Balia, R., Bosmann, C., Cardarelli, E. \& Deidda, R. (2000) Some consideration on shallow seismic reflection surveys. Journal of Applied Geophysics, 45, 127-139

Foti, S., Sambuelli, L., Socco, V. L., \& Strobbia, C. (2003). Experiments of joint acquisition of seismic refraction and surface wave data. Near surface geophysics, 1(3), 119-129.

Garambois, S., Sénéchal, P. \& Perroud, H. (2002). On the use of combined geophysical methods to assess water content and water conductivity of near surface formations. Journal of Hydrology, 259 (1), 32-48.

Gassmann, F. (1951). Elasticity of porous media. Vierteljahrsschrder Naturforschenden Gesselschaft, 96, 1-23.

Geist, D. J., McBirney, A. R., \& Duncan, R. A. (1986). Geology and petrogenesis of lavas from San Cristobal Island, Galapagos archipelago. Geological Society of America Bulletin, 97(5), 555-566.

Geist, D., Naumann, T., \& Larson, P. (1998). Evolution of Galápagos magmas: Mantle and crustal fractionation without assimilation. Journal of Petrology, 39(5), 953-971.

Grab, M., Zürcher, B., Maurer, H., \& Greenhalgh, S. (2015). Seismic velocity structure of a fossilized Icelandic geothermal system: A combined laboratory and field study. Geothermics, 57, 84-94.

Grelle, G., \& Guadagno, F. M. (2009). Seismic refraction methodology for groundwater level determination:"Water seismic index". Journal of Applied Geophysics, 68(3), 301-320. 
Haeni, F. P. (1988). Application of seismic-refraction techniques to hydrologic studies. US Government Printing Office.

Ingebritsen, S. E., \& Scholl, M. A. (1993). The hydrogeology of Kilauea volcano. Geothermics, 22(4), 255-270.

Izquierdo, T., Dominguez, C., Violette, S. and Villacis, M. (2015). Volcanic island evolution and their implications for the groundwater conceptual model development in San Cristóbal (Galápagos). In 42nd IAH Congress 2015.

Kearey, P., Brooks, M., \& Hill, I. (2013). An introduction to geophysical exploration. John Wiley \& Sons.

Keiswetter, D. A., \& Steeples, D. W. (1995). A field investigation of source parameters for the sledgehammer. Geophysics, 60(4), 1051-1057.

Khalil, M. H., \& Hanafy, S. M. (2008). Engineering applications of seismic refraction method: A field example at Wadi Wardan, Northeast Gulf of Suez, Sinai, Egypt. Journal of Applied Geophysics, 65(3), 132-141.

Krivochieva, S., \& Chouteau, M. (2003). Integrating TDEM and MT methods for characterization and delineation of the Santa Catarina aquifer (Chalco Sub-Basin, Mexico). Journal of Applied Geophysics, 52(1), 23-43.

Lienert, B. R. (1991). An electromagnetic study of Maui's last active volcano. Geophysics, 56(7), 972982.

Loaiza Ambuludi, S. (2012). Étude des propriétés physiques et du comportement mécanique des Basaltes: étude cinétique, mécanistique et toxicologique de l'oxydation dégradante de l'Ibuprofène par l'oxydation avancée électrochimique et photochimique (Doctoral dissertation, Paris Est).

Mari, J. L. (1999). Geophysics of reservoir and civil engineering. Editions Technip.

McBirney, A. R., \& Williams, H. (1969). Geology and petrology of the Galapagos Islands. Geological Society of America Memoirs, 118, 1-197.

Murphy, W. F. (1985). Sonic and ultrasonic velocities: theory versus experiment. Geophysical Research Letters, 12(2), 85-88.

Pálmason, G. (1965). Seismic refraction measurements of the basalt lavas of the Faeroe Islands. Tectonophysics, 2(6), 475-482.

Pryet, A. (2011a). Hydrogeology of volcanic islands: a case-study in the Galapagos Archipelago. Doctoral dissertation, Ph. D. thesis, Université Pierre et Marie Curie, Paris.

Pryet, A., Ramm, J., Chilès, J. P., Auken, E., Deffontaines, B., \& Violette, S. (2011b). 3D resistivity gridding of large AEM datasets: a step toward enhanced geological interpretation. Journal of Applied Geophysics, 75(2), 277-283. 
Pryet, A., d'Ozouville, N., Violette, S., Deffontaines, B., \& Auken, E. (2012a). Hydrogeological settings of a volcanic island (San Cristóbal, Galapagos) from joint interpretation of airborne electromagnetics and geomorphological observations. Hydrology and Earth System Sciences, 16(12), 4571-4579.

Pryet, A., Dominguez, C., Tomai, P. F., Chaumont, C., d'Ozouville, N., Villacís, M., \& Violette, S. (2012b). Quantification of cloud water interception along the windward slope of Santa Cruz Island, Galapagos (Ecuador). Agricultural and forest meteorology, 161, 94-106.

Pasquet, S., L. Bodet, L. Longuevergne, A. Dhemaied, C. Camerlynck, F. Rejiba, and R. Guérin (2015), $2 \mathrm{D}$ characterization of near-surface $\mathrm{V} P / \mathrm{V}$ S: surface-wave dispersion inversion versus refraction tomography, Near Surf. Geophys., 13(2089), 315-331.

Revil, A., Naudet, V., \& Meunier, J. D. (2004). The hydroelectric problem of porous rocks: inversion of the position of the water table from self-potential data. Geophysical Journal International,159(2), 435-444.

Revil, A., Finizola, A., Piscitelli, S., Rizzo, E., Ricci, T., Crespy, A., ... \& Bolève, A. (2008). Inner structure of La Fossa di Vulcano (Vulcano Island, southern Tyrrhenian Sea, Italy) revealed by high-resolution electric resistivity tomography coupled with self-potential, temperature, and $\mathrm{CO} 2$ diffuse degassing measurements. Journal of Geophysical Research: Solid Earth,113(B7).

Saar, M. O., \& Manga, M. (1999). Permeability-porosity relationship in vesicular basalts. Geophys. Res. Lett, 26(1), 111-114.

Schaefer, L. N., Kendrick, J. E., Oommen, T., Lavallée, Y., \& Chigna, G. (2015). Geomechanical rock properties of a basaltic volcano. Frontiers in Earth Science, 3, 29.

Schultz, R. A. (1995). Limits on strength and deformation properties of jointed basaltic rock masses. Rock Mechanics and Rock Engineering, 28(1), 1-15.

Siratovich, P. A., Heap, M. J., Villenueve, M. C., Cole, J. W., \& Reuschlé, T. (2014). Physical property relationships of the Rotokawa Andesite, a significant geothermal reservoir rock in the Taupo Volcanic Zone, New Zealand. Geothermal Energy, 2(1), 1.

Uhlemann, S., S. Hagedorn, B. Dashwood, H. Maurer, D. Gunn, T. Dijkstra, and J. Chambers (2016), Landslide characterization using P- and S-wave seismic refraction tomography - The importance of elastic moduli, J. Appl. Geophys., 134, 64-76.

Violette, S., Ledoux, E., Goblet, P. \& Carbonnel, J.-P., (1997). Hydrologic and thermal modelling of an active volcano: the "Piton de la Fournaise, La Réunion Island". Journal of hydrology, 191, 3763Violette, S., d'Ozouville, N., Pryet, A., Deffontaines, B., Fortin, J., \& Adelinet, M. (2014). Hydrogeology of the Galapagos Archipelago: an integrated and comparative approach between islands. The Galapagos: A Natural Laboratory for the Earth Sciences, 204, 167.

Vittecoq, B., Deparis, J., Violette, S., Jaouen, T., \& Lacquement, F. (2014). Influence of successive phases of volcanic construction and erosion on Mayotte Island's hydrogeological functioning as determined from a helicopter-borne resistivity survey correlated with borehole geological and permeability data. Journal of Hydrology, 509, 519-538. 
732 Vittecoq B., Reninger, P.-A., Violette, S., Martelet, G., Dewandel, B., Audru, J.-C., (2015). 733 Heterogeneity of hydrodynamic properties and groundwater circulation of a coastal andesitic 734 volcanic aquifer controlled by tectonic induced faults and rock fracturing - Martinique Island (Lesser 735 Antilles - FWI). Journal of Hydrology, 529, 1041-1059, doi:10.1016/j.jhydrol.2015.09.022

736 White, W. M., McBirney, A. R., \& Duncan, R. A. (1993). Petrology and geochemistry of the Galápagos 737 Islands: Portrait of a pathological mantle plume. Journal of Geophysical Research: Solid 738 Earth, 98(B11), 19533-19563.

739 Williams, R. A., Stephenson, W. J., \& Odum, J. K. (2003). Comparison of P-and S-wave velocity profiles 740 obtained from surface seismic refraction/reflection and downhole data. Tectonophysics, 368(1), 71 74188.

742 Zhang, J., and Toksoz, M. (1998) Non-linear refraction travel-time tomography. Geophysics, 63, 17267431737. 


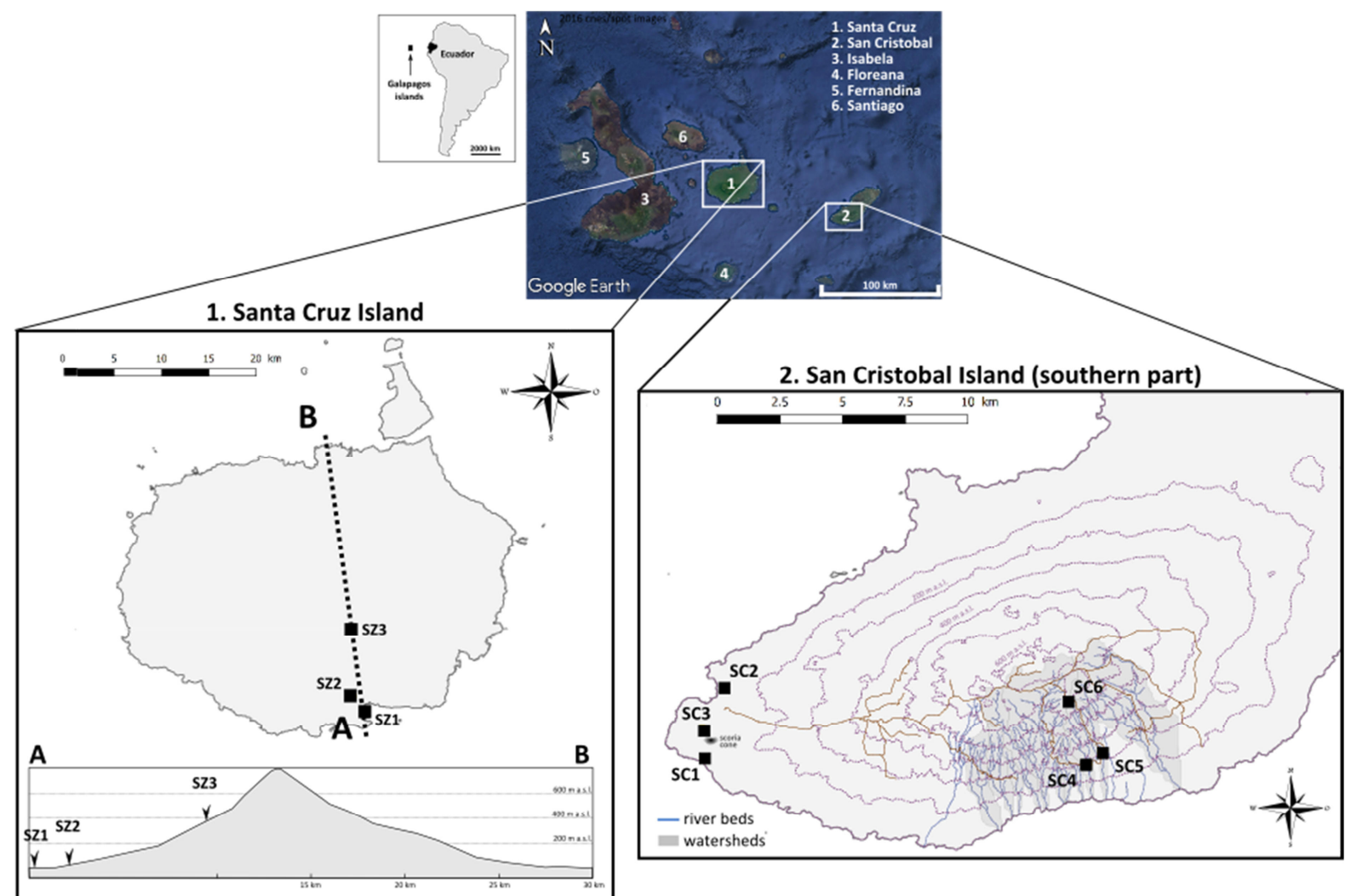

748 Figure 1 - Location of seismic site surveys (background of top picture: (CGoogle Earth image). We investigated three sites on Santa Cruz Island ( 2 near the coast and 1 in the highlands) and six sites on San Cristobal Island split into three coastal, two mid-slope and one highland sites. 


\section{Santa Cruz sites}
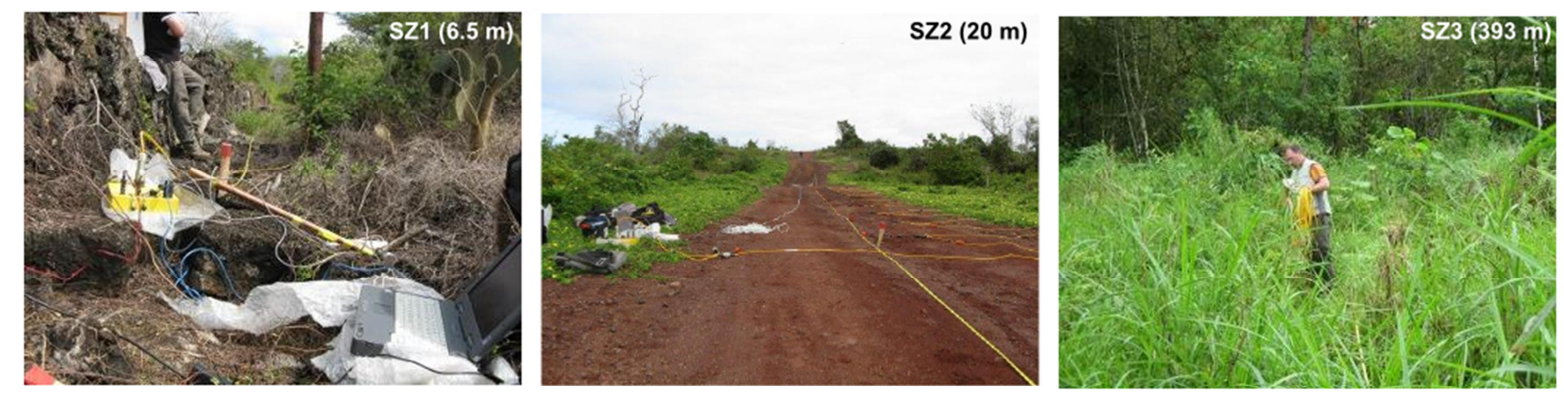

\section{San Cristobal sites}

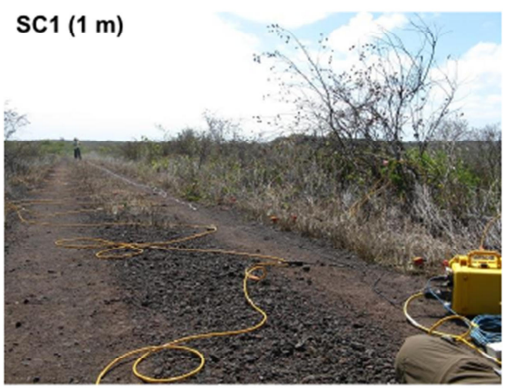

$\operatorname{sc2}(8 \mathrm{~m})$
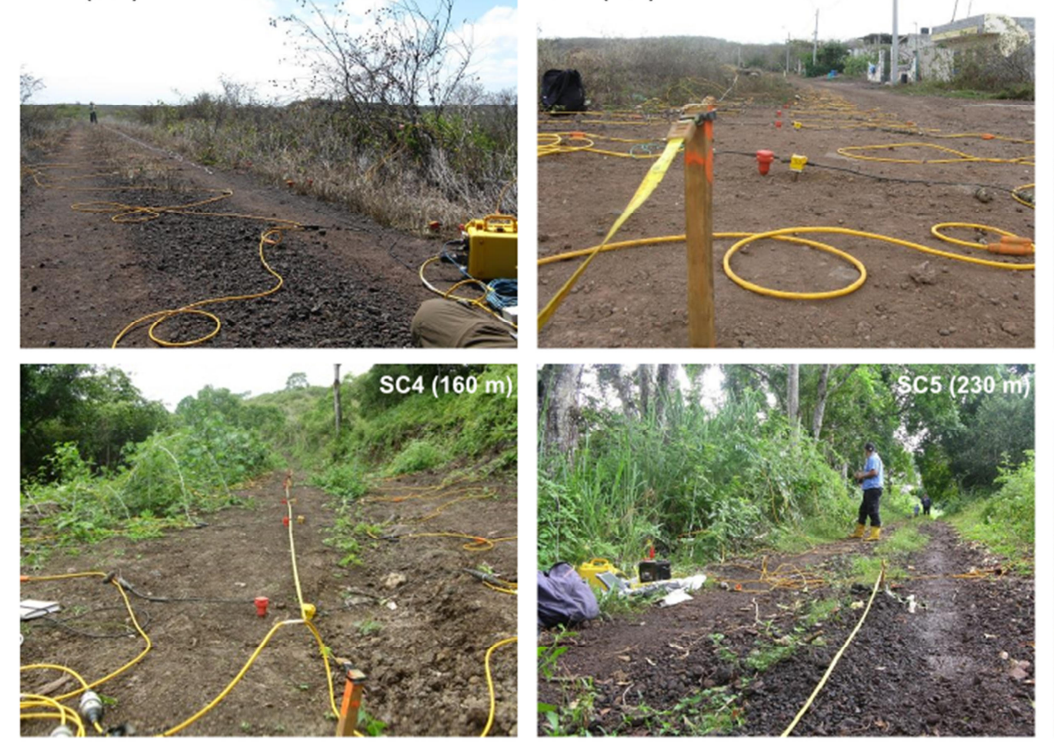

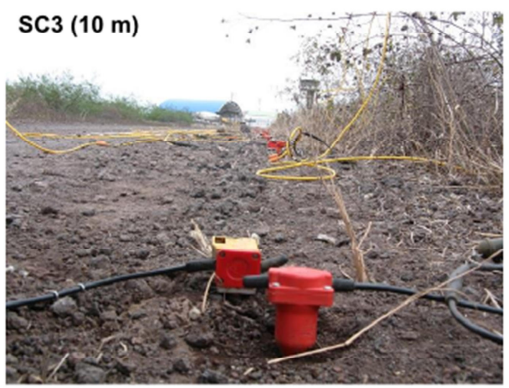

SC6 (590 m)

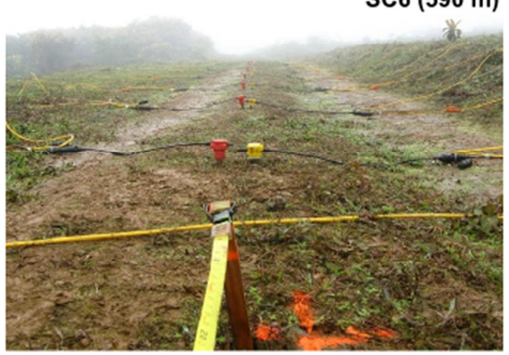

Figure 2 - Pictures of investigated sites according altitude. 


\section{A. San Cristobal elevation map}

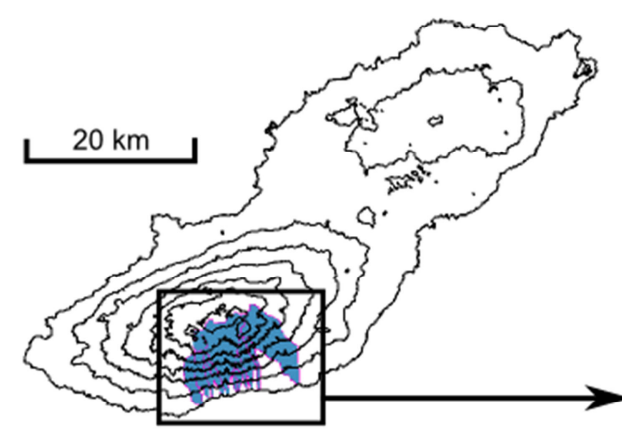

C. San Cristobal mid-slope sites

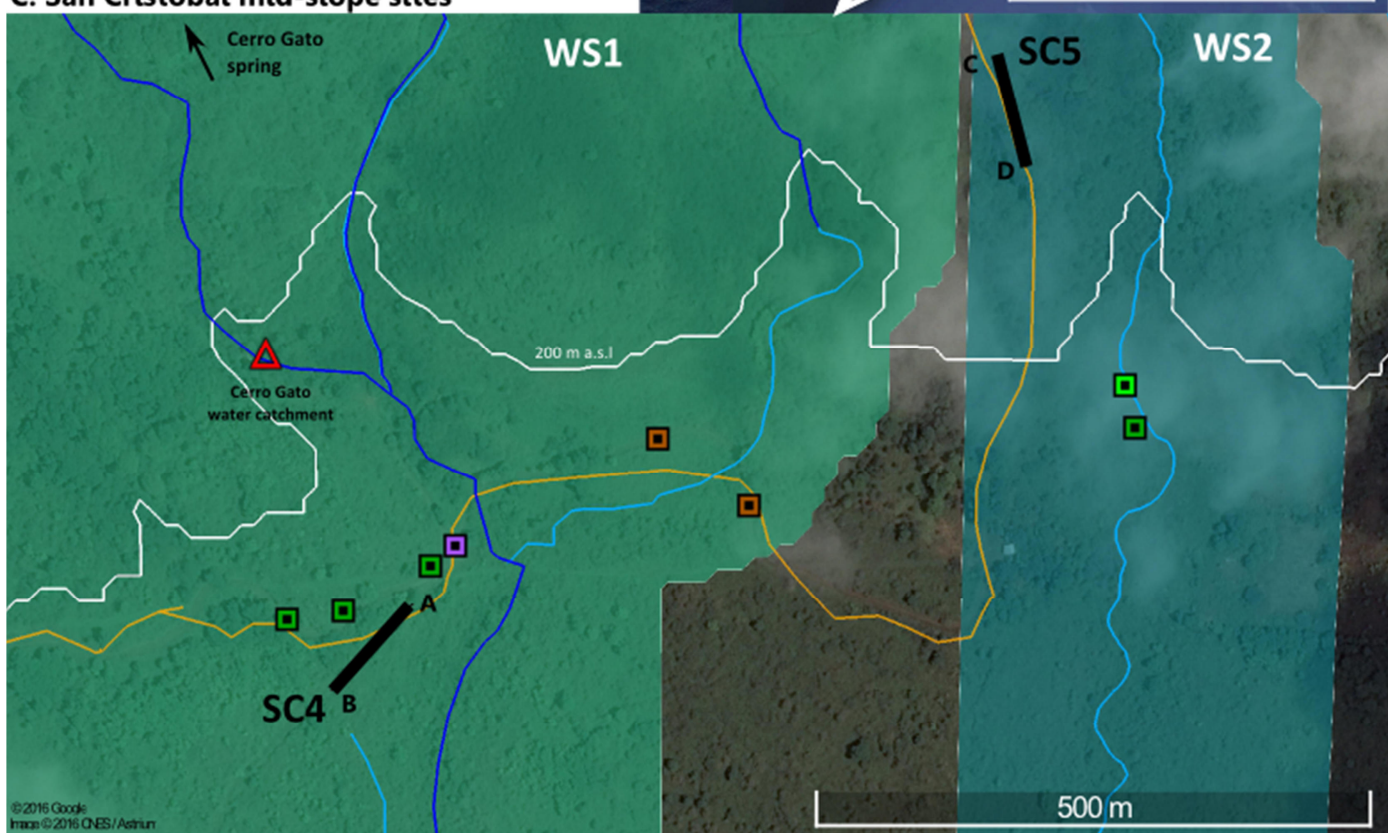

\section{Outcrop description}

口 Pyroclastic deposits

Weathered lava flow

$\square$ Low-weathered lava flow

ㅁ. Soil

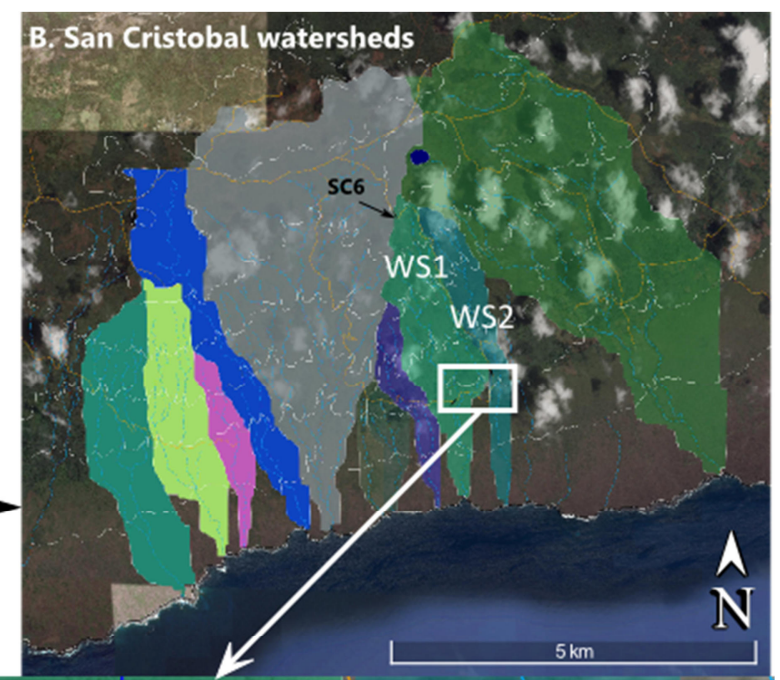

Surface hydrology

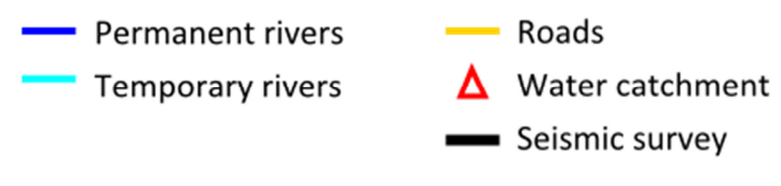

Figure 3 - Spatial configuration of seismic-refraction layouts for mid-slope sites on San Cristobal 
A. Santa Cruz layout

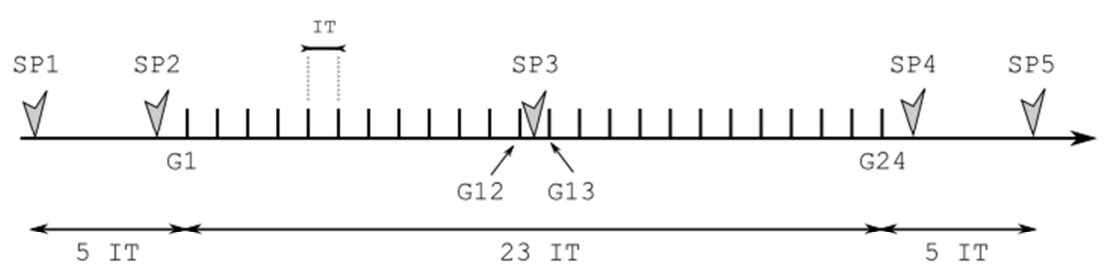

B. San Cristobal layout (96 m seismic spread)

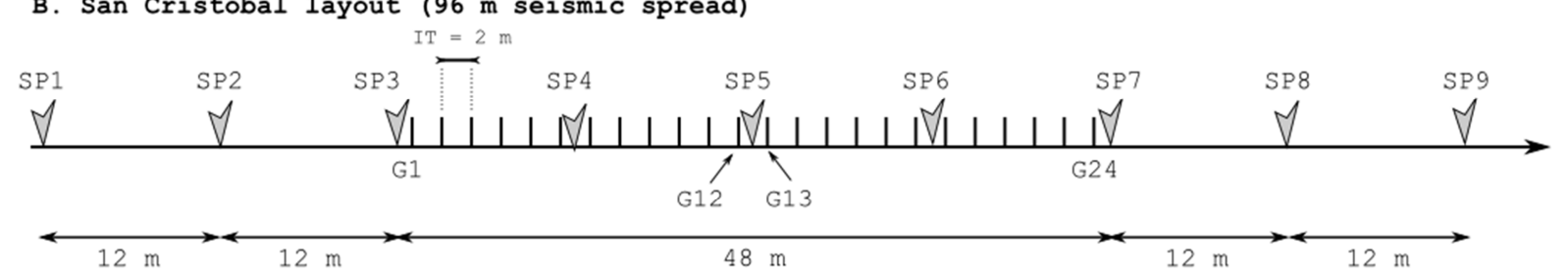

Figure 4 - Seismic-refraction survey layouts on both islands. On Santa Cruz, the intertrace is variable according the depth of the expected refractor target: $1 \mathrm{~m}$ (SZ1), $2 \mathrm{~m}$ (SZ2), $5 \mathrm{~m}$ (SZ3). Shot points (SP) for Santa Cruz sites are spread as follows: 1 central (SP3) and 4 end-off shots. On San Cristobal, the intertrace is always the same for the 6 sites $(2 \mathrm{~m})$ and 9 SP are equally distributed on the lines (each 12 meters).

764

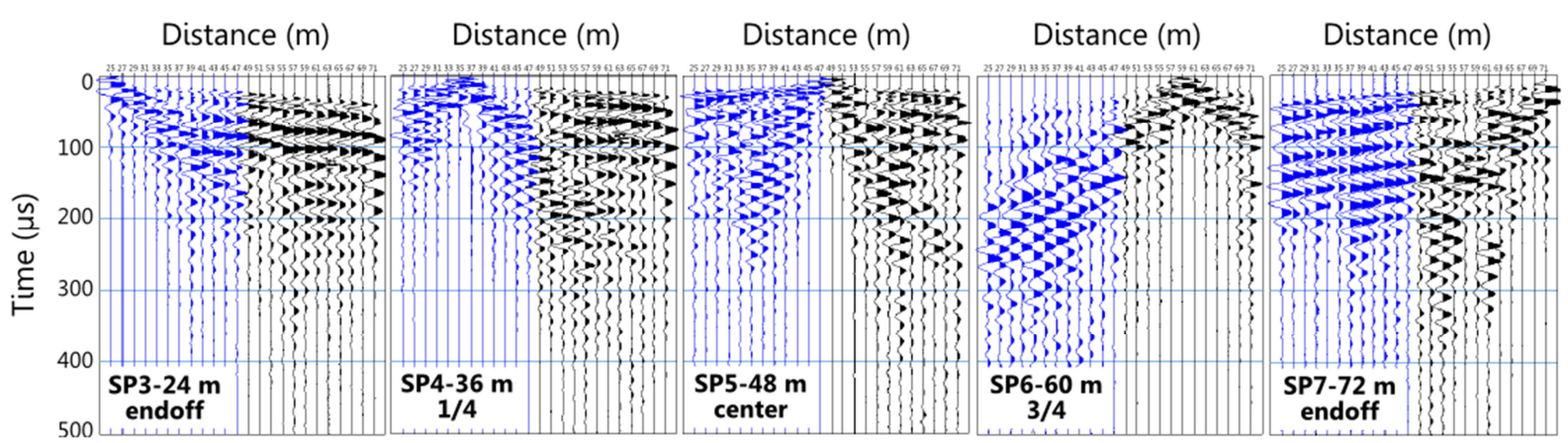

Figure 5 - Shot gathers recorded for profile SC3. Trace amplitudes are normalized for display 
3. Initial velocity model (20 layers)

1. First break peaking
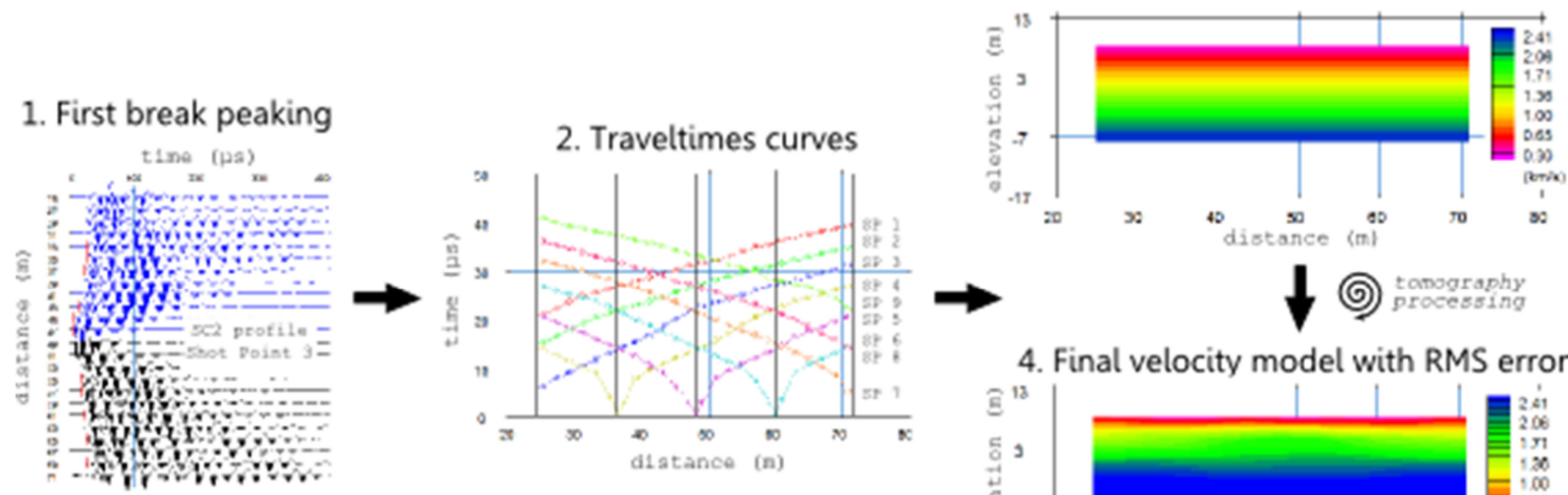

4. Final velocity model with RMS error

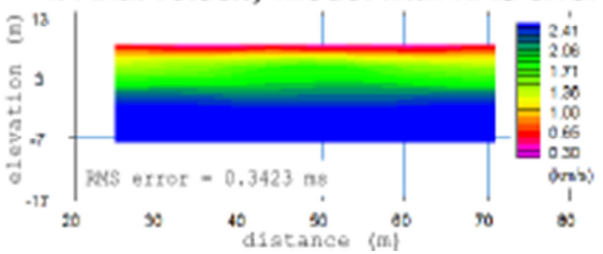

Figure 6 - General methodology of seismic-refraction processing made on the Galapagos data. SeisImager Geometrics softwares were used for first break picking (Pickwin module) and tomography iterative process (PlotRefra module). 


\section{A. Comparison between observed and calculated traveltimes}

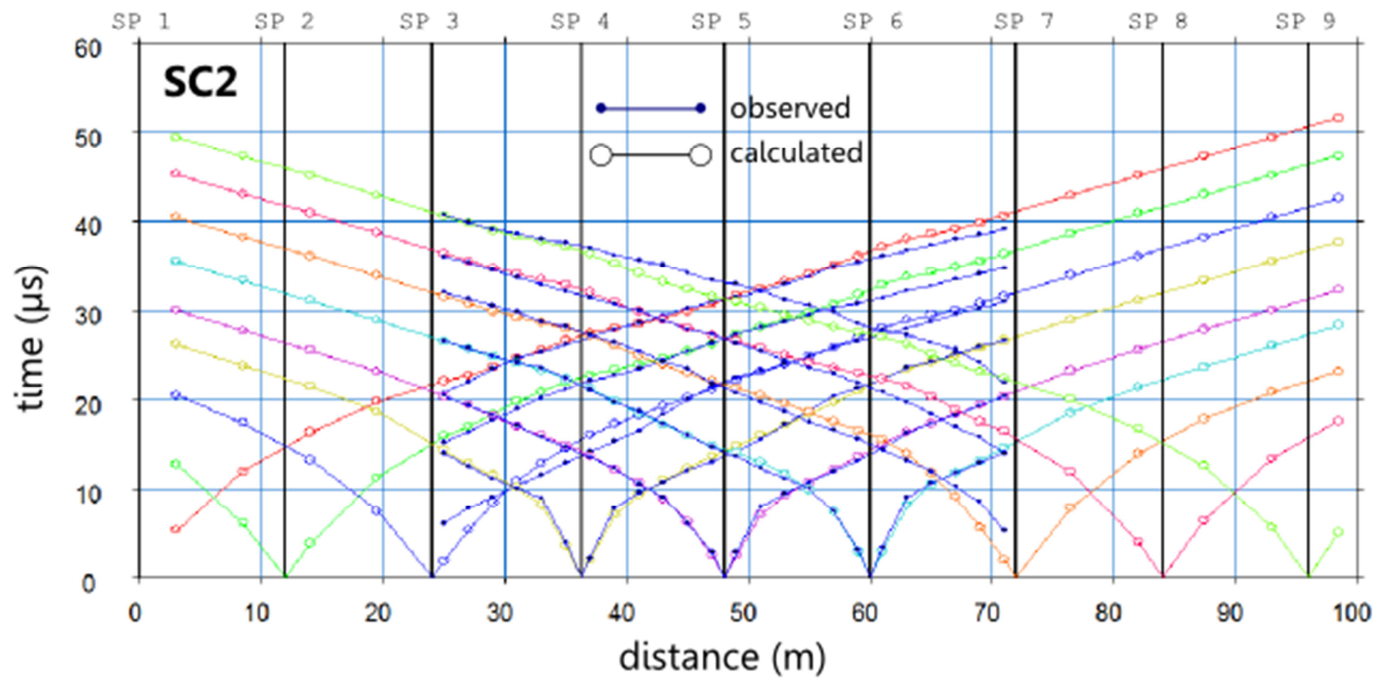

B. Best tomography model and associated ray-paths

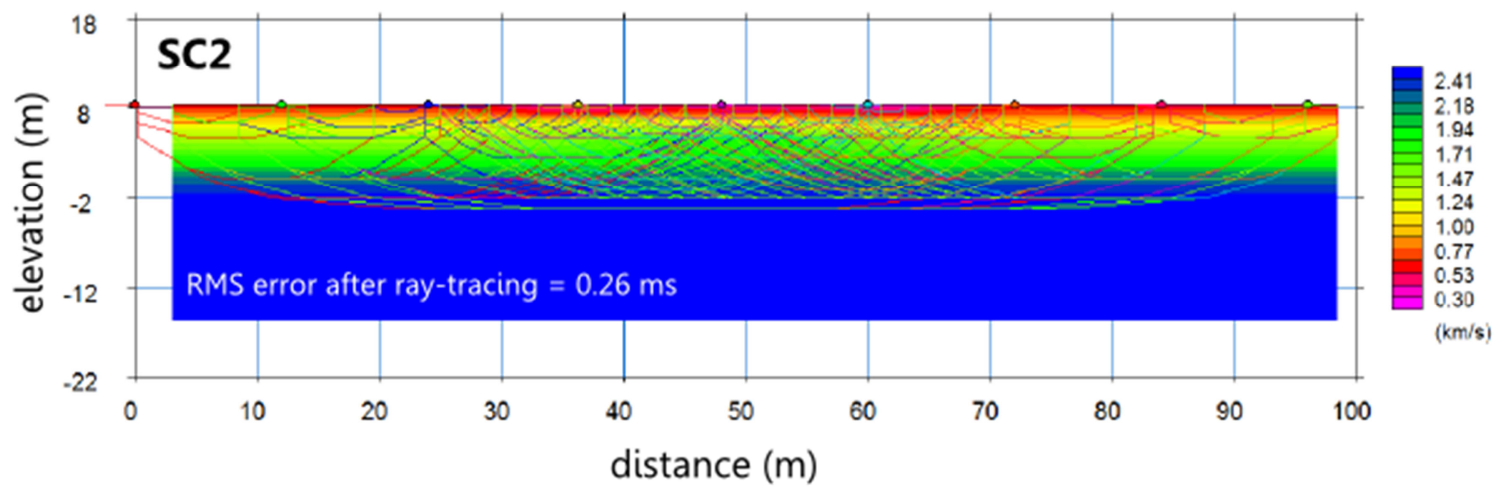

C. Root mean square (RMS) error curve for the 20 iterations

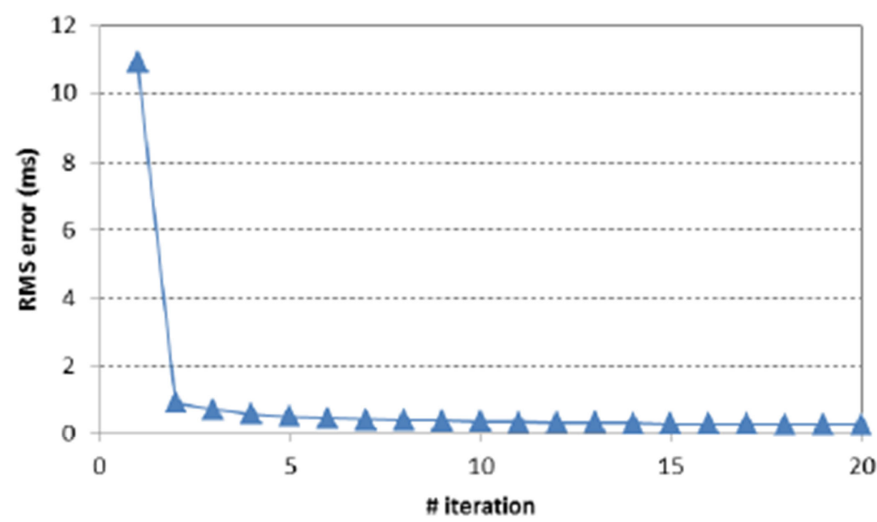

Figure 7 - Example of raypath processing to ckeck the tomography inversion quality. Example of 

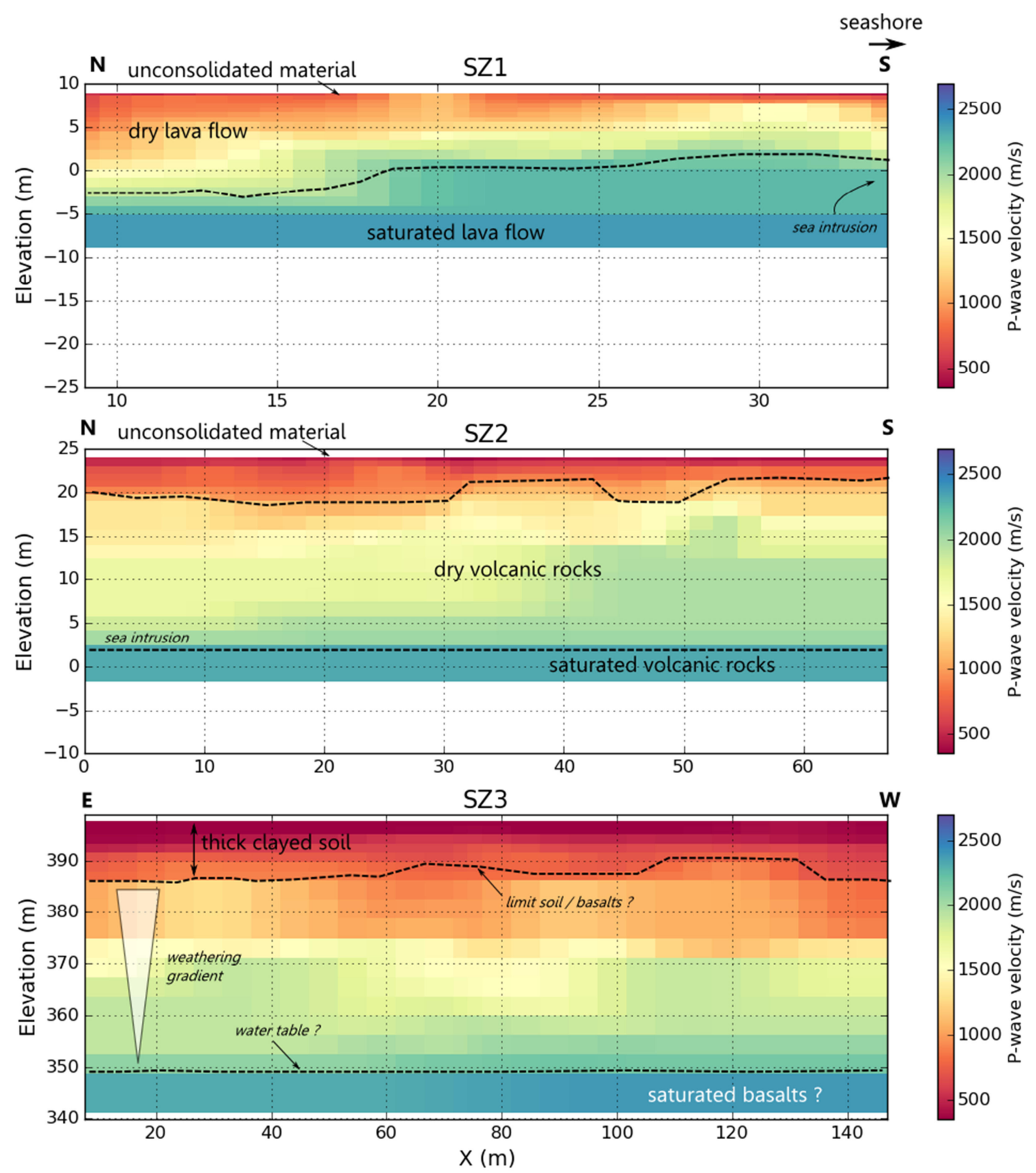

780 Figure 8 - Results obtained on Santa Cruz Island. Contrast between dry and water-saturated layers 781 is observed. The interface is interpreted as the salted wedge near from the coast. For the highland 782 site SZ3, the transition is smoother and can be interpreted more as a progressive water saturation 783 profile in weathered material. 

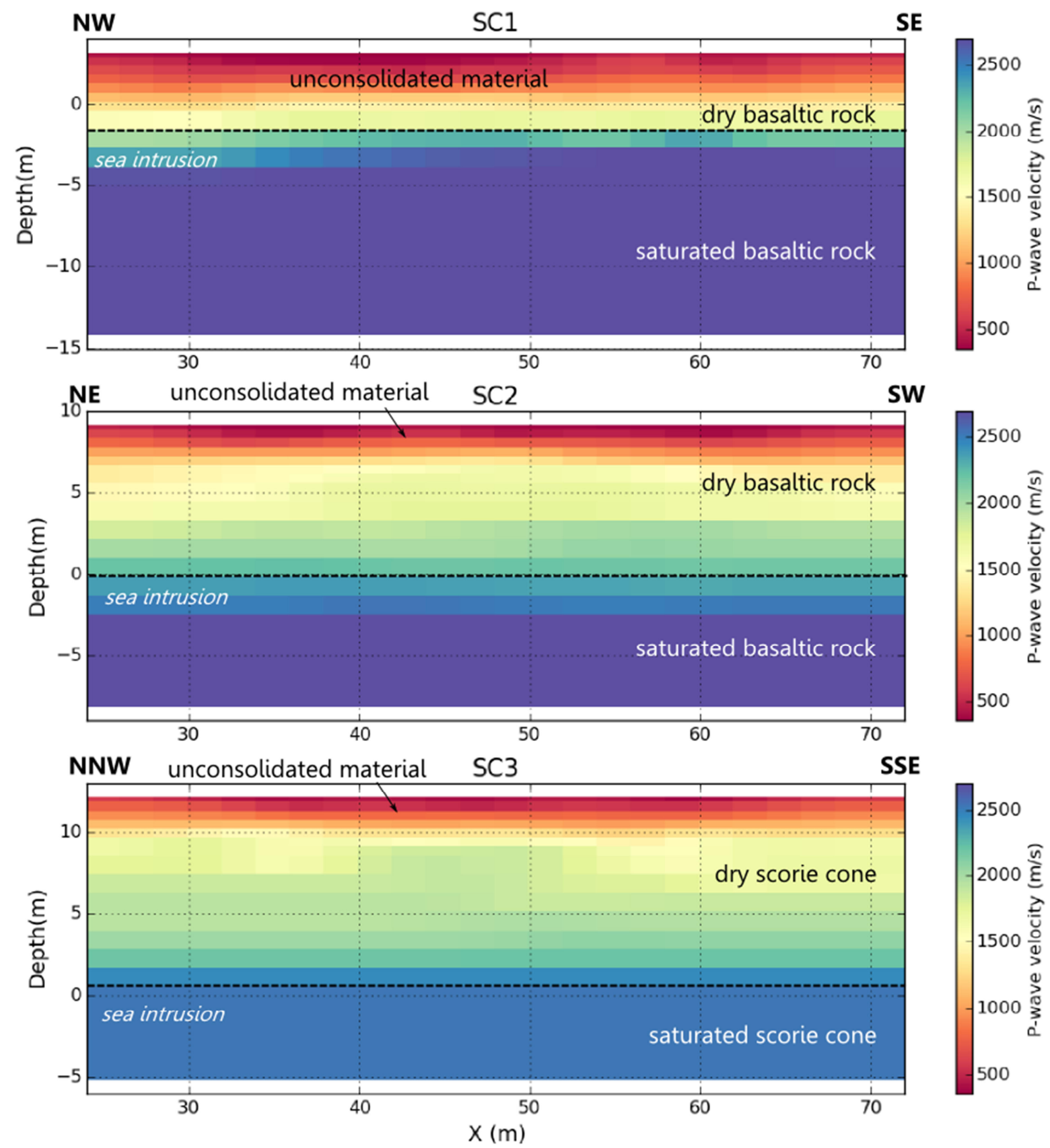

785 Figure 9 - Velocity profiles obtained for coastal sites on San Cristobal Island. As for Santa Cruz 786 profiles, a sharp contrast between low and high-velocity layer is observed corresponding to the 787 contrast between dry and saturated layers in depth. The scoria site (SC3) presents velocities lower 788 than basaltic sites (SC1 and SC2). 
$\longleftarrow$ Cerro Gato steam
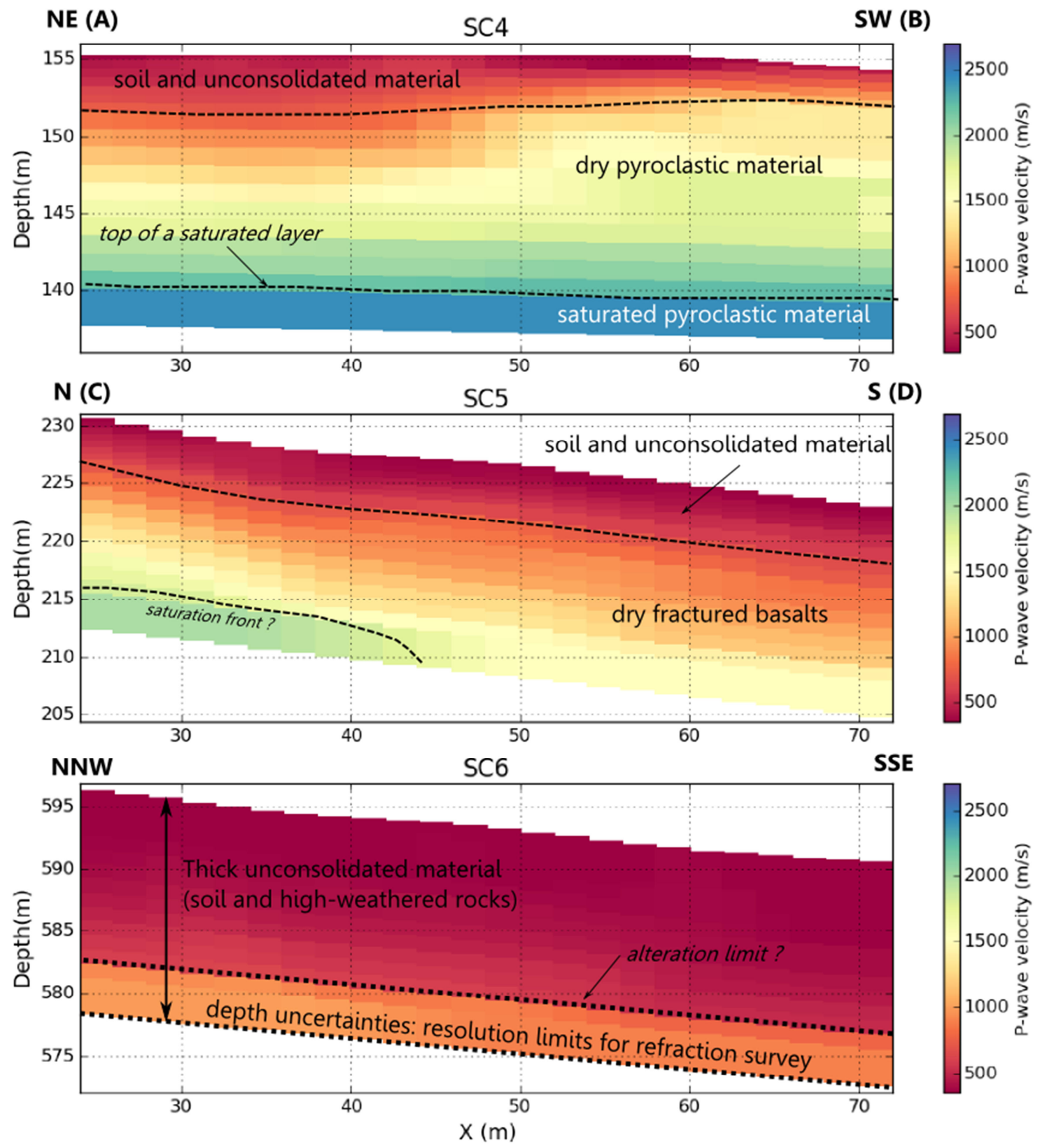

Figure 10 - Velocity profiles obtained for land sites on San Cristobal Island. SC4 presents both dry and saturated velocity layer. The interface is interpreted here as the top of a freshwater saturated aquifer. Whereas SC5 is located also in the mid-slope of the island, it presents only dry velocities in depth. Limits of refraction resolution are achieved for highland site SC6 without any refractor in depth. Only unconsolidated material has been investigated (probably soil and highly weathered 


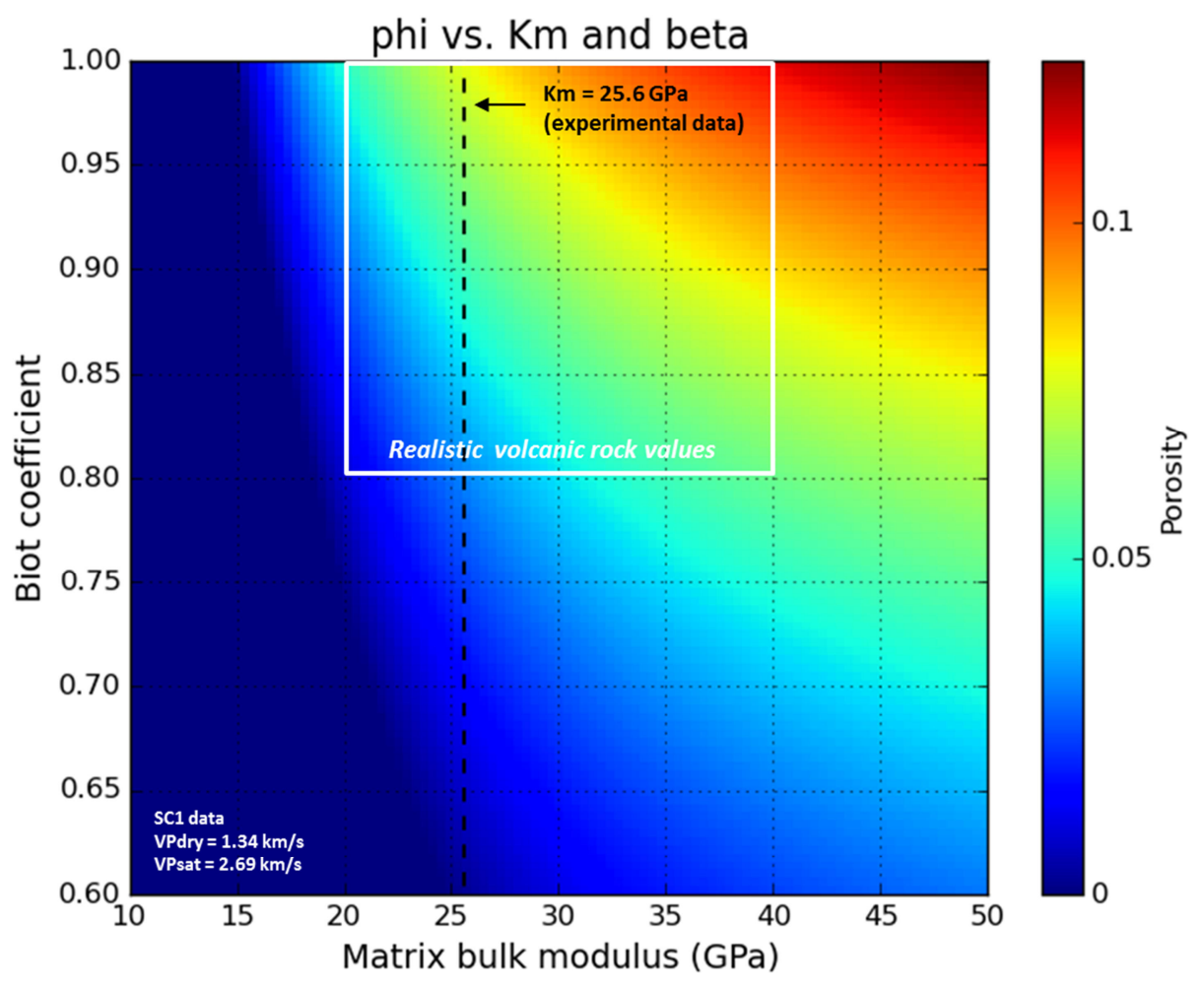

Figure 11 - Sensitivity approach on the effect of Biot coefficient and matrix bulk modulus on inverted porosities using SC1 input velocity data.

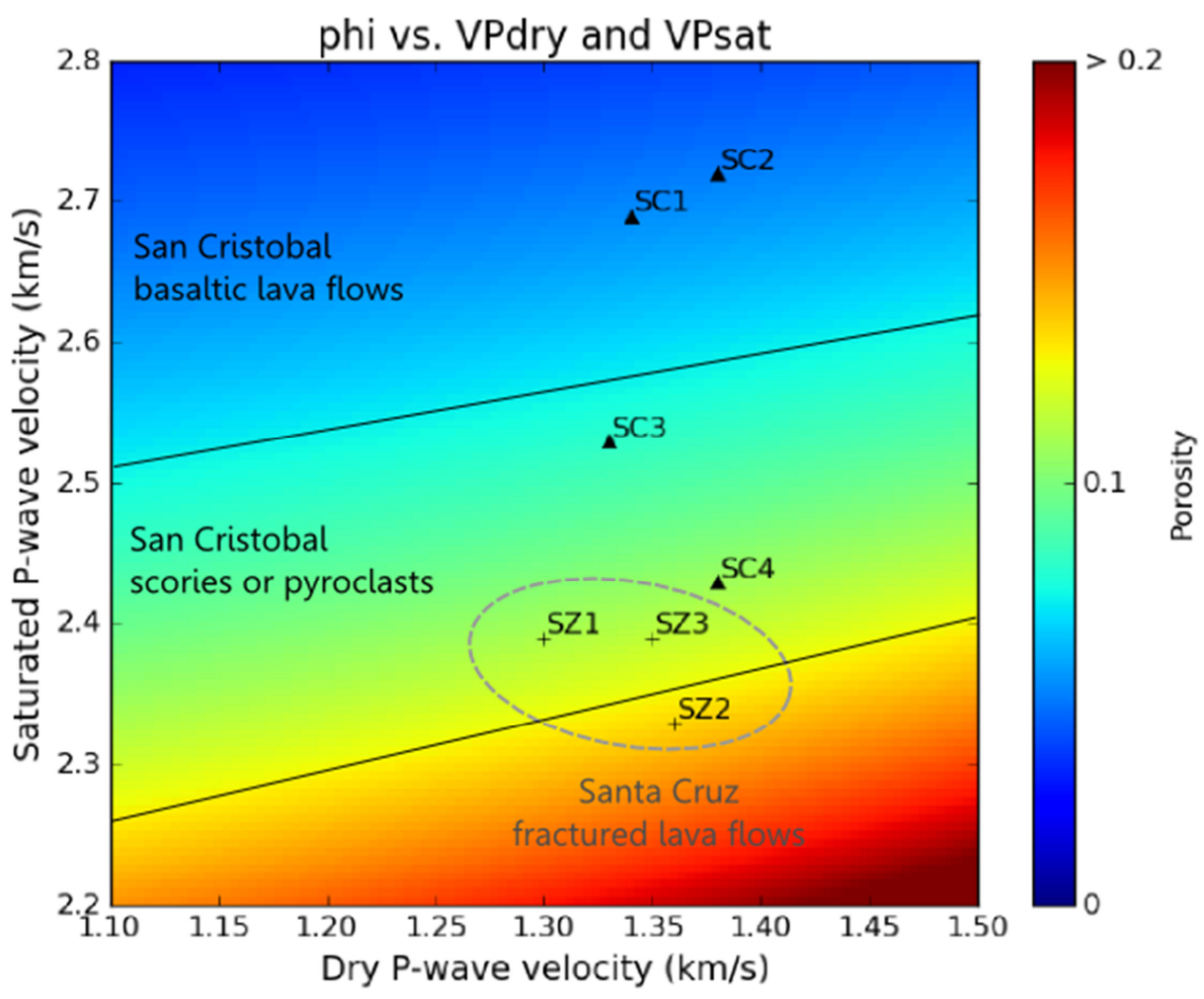

Figure 12 - Modelling porosity from field P-wave velocities. Different San Cristobal lithologies are identified according inverted porosities: basaltic bedrocks (SC1 and SC2) or scoria / pyroclast cones

(SC3 and SC4). The three sites of Santa Cruz are close, probably due to high fracturation in the bedrock. 